\title{
Direct Delivery of Antigens to Dendritic Cells via Antibodies Specific for Endocytic Receptors as a Promising Strategy for Future Therapies
}

\author{
Christian H. K. Lehmann ${ }^{1}$, Lukas Heger ${ }^{1}$, Gordon F. Heidkamp ${ }^{1}$, Anna Baranska ${ }^{1,2}$, \\ Jennifer J. Lühr ${ }^{1}$, Alana Hoffmann ${ }^{1}$ and Diana Dudziak ${ }^{1, *}$ \\ 1 Laboratory of DC-Biology, Department of Dermatology, Friedrich-Alexander-Universität \\ Erlangen-Nürnberg, University Hospital Erlangen, Hartmannstr. 14, Erlangen 91052, Germany; \\ christian.lehmann@uk-erlangen.de (C.H.K.L.); lukas.heger@uk-erlangen.de (L.H.); \\ gordon.heidkamp@uk-erlangen.de (G.F.H.); baranska@ciml.univ-mrs.fr (A.B.); \\ jennifer.lühr@uk-erlangen.de (J.J.L.); alana.hoffmann@uk-erlangen.de (A.H.) \\ 2 Centre d'Immunologie de Marseille-Luminy, Aix Marseille Université, INSERM-CNRS, \\ Marseille-Luminy 13288, France \\ * Correspondence: diana.dudziak@uk-erlangen.de; Tel.: +49-9131-85-39346; Fax: +49-9131-85-39347 \\ Academic Editor: Diane M. Harper \\ Received: 19 February 2016; Accepted: 18 March 2016; Published: 28 March 2016
}

\begin{abstract}
Dendritic cells (DCs) are the most potent professional antigen presenting cells and are therefore indispensable for the control of immunity. The technique of antibody mediated antigen targeting to DC subsets has been the basis of intense research for more than a decade. Many murine studies have utilized this approach of antigen delivery to various kinds of endocytic receptors of DCs both in vitro and in vivo. Today, it is widely accepted that different DC subsets are important for the induction of select immune responses. Nevertheless, many questions still remain to be answered, such as the actual influence of the targeted receptor on the initiation of the immune response to the delivered antigen. Further efforts to better understand the induction of antigen-specific immune responses will support the transfer of this knowledge into novel treatment strategies for human diseases. In this review, we will discuss the state-of-the-art aspects of the basic principles of antibody mediated antigen targeting approaches. A table will also provide a broad overview of the latest studies using antigen targeting including addressed DC subset, targeted receptors, outcome, and applied coupling techniques.
\end{abstract}

Keywords: antigen targeting; antigen targeting antibodies; cancer; CLR; DC; DCIR; DEC205; dendritic cell subsets; moDC; vaccine

\section{Introduction}

One of the crucial abilities of the immune system is the distinction between self- and pathogen-derived antigens. Professional antigen presenting cells, especially Dendritic cells (DCs), not only present engulfed and processed self- and foreign antigens as peptide MHC complexes (pMHC) on their surface, they also reflect their environment by the surface expression status of co-stimulatory molecules (e.g., CD80 (B7-1), CD86 (B7-2)), activation markers (CD40, CD83), and the secretion level of cytokines (e.g., IL-12) and chemokines [1,2]. Thus, the presentation of pathogen-derived peptides in an inflammatory context allows for the induction of protective immune responses against the invading pathogen, while the presentation of (self-)antigens in a non-inflammatory context maintains peripheral tolerance [2-13]. These capabilities define DCs as one of the key players within the immune system. 


\section{Pattern Recognition Receptors}

Germline-encoded pattern recognition receptors (PRRs) enable DCs to detect danger signals such as conserved pathogen-associated molecular patterns (PAMPs) or other shared structures of various pathogens like fungi, bacteria, helminthes, and viruses (reviewed in [10,14-22]). Triggering of PRRs, which are also expressed on a variety of other immune cells, can lead to the uptake of pathogens or pathogen-derived material and/or to cell activation [12,23,24]. Besides nucleotide-binding oligomerization domain proteins (NOD) or retinoic acid inducible gene 1-like receptors (RIG-I), two prominent PRR family members are Toll like receptors (TLRs) and C type lectin receptors (CLRs, Clec) [22].

TLRs are type I integral membrane glycoproteins and well characterized members of the PRR family. They are localized in the plasma membrane (TLRs 1, 2, 4, 5, 6, 11) or in endosomal compartments (TLRs 3, 7, 8, 9) $[14,25,26]$. The endosomal TLRs are responsible for sensing nucleic acids such as bacterial or viral RNAs and DNAs, while the TLRs of the plasma membrane are able to recognize pathogen-derived sugars, lipoproteins, protozoa, or fungal cell wall components. TLR ligand recognition leads to signal transduction, transcription factor activation, and finally DC maturation including upregulation of co-stimulatory molecules and secretion of pro-inflammatory cytokines [22,27]. The recognition of PAMPs is guided by leucine-rich repeats, while the cytoplasmic Toll/IL-1 receptor (TIR) domain is responsible for downstream signaling [15].

CLRs are a diverse family of calcium dependent molecules situated in the cellular plasma-membrane. They can be distinguished into type I (DEC205, MMR) and type II transmembrane proteins (almost all other CLRs), displaying the N-terminus either outside or inside the cell, respectively. By their carbohydrate recognition domain (CRD), CLRs are able to sense self- and non-self-sugar side chains of proteins such as N-glycans, O-glycans, and glycosphingolipid motifs [28]. The specificity for mannose enables the detection of viruses, fungi, and mycobacteria, while the specificity for fucose allows for the recognition of certain bacteria and helminths. Moreover, glucan structures are expressed by mycobacteria and fungi $[29,30]$. CLRs are capable to not only bind the sugar side chains; they also trigger endocytosis of the bound material. This process can then lead to processing and presentation of antigens as peptide-MHC complexes on the DC surface. In dependency of the intracellular signaling motif, which can be an inhibitory ITIM (immunoreceptor tyrosine-based inhibitory motif) or activating ITAM (immunoreceptor tyrosine-based activating motif), binding of a natural ligand to the CLR can induce either inhibiting or activating signaling pathways in the cell, respectively. The latter ones (in combination with TLR signaling or outside type I interferon) are important for a full DC maturation and presentation of antigens under inflammatory conditions [14,26,29].

Besides the recognition of pathogens, DCs are also capable to sense, take up, process, and present self-antigens derived from apoptotic cells, cell debris, or damaged cells, which are recognized as damage-associated molecular patterns (DAMPs) [31-33]. This detection and uptake is implemented by the expression of scavenger receptors as well as CLRs, as shown for Clec9A [34]. Due to defective ribosomal products (DRIPs), which are derived from short lived, aborted, or mis-folded proteins, also self-peptides can be presented on the DC surface [35]. The presentation of self-peptides is necessary to counterbalance potential auto-reactive $\mathrm{T}$ cells, which might have escaped negative selection processes in the thymus. T cells, which interact with self-peptides complexed to MHC molecules on immature/semi-mature DCs under steady-state conditions undergo anergic mechanisms (unresponsiveness) or will be deleted. Therefore, antigen presentation by steady-state DCs is an important checkpoint for the maintenance of peripheral tolerance. This control might be accompanied by the help of regulatory $\mathrm{T}$ cells $[5-7,36,37]$.

Overall, the ability of effective antigen uptake, processing, and presentation as well as the regulation of immunogenic and tolerogenic immune responses renders DCs as promising candidate cells for immunotherapeutic approaches [38-43]. 


\section{Monocyte-Derived DCs in Immunotherapeutic Approaches}

As DCs are essential for the presentation of antigenic peptides to $T$ cells and thereby enabling them to elicit potent antigen-specific immune responses to pathogens and tumor cells, the idea of utilizing DCs for cancer treatment has already emerged several years ago [43,44]. One fundamental initial discovery for current therapeutic approaches was that human peripheral blood monocytes could be differentiated into monocyte-derived DCs (moDCs) by a combination of growth factors and cytokines, namely GM-CSF (granulocyte macrophage colony-stimulating factor) and IL-4 (Interleukin 4) (Figure 1a) [45-49].

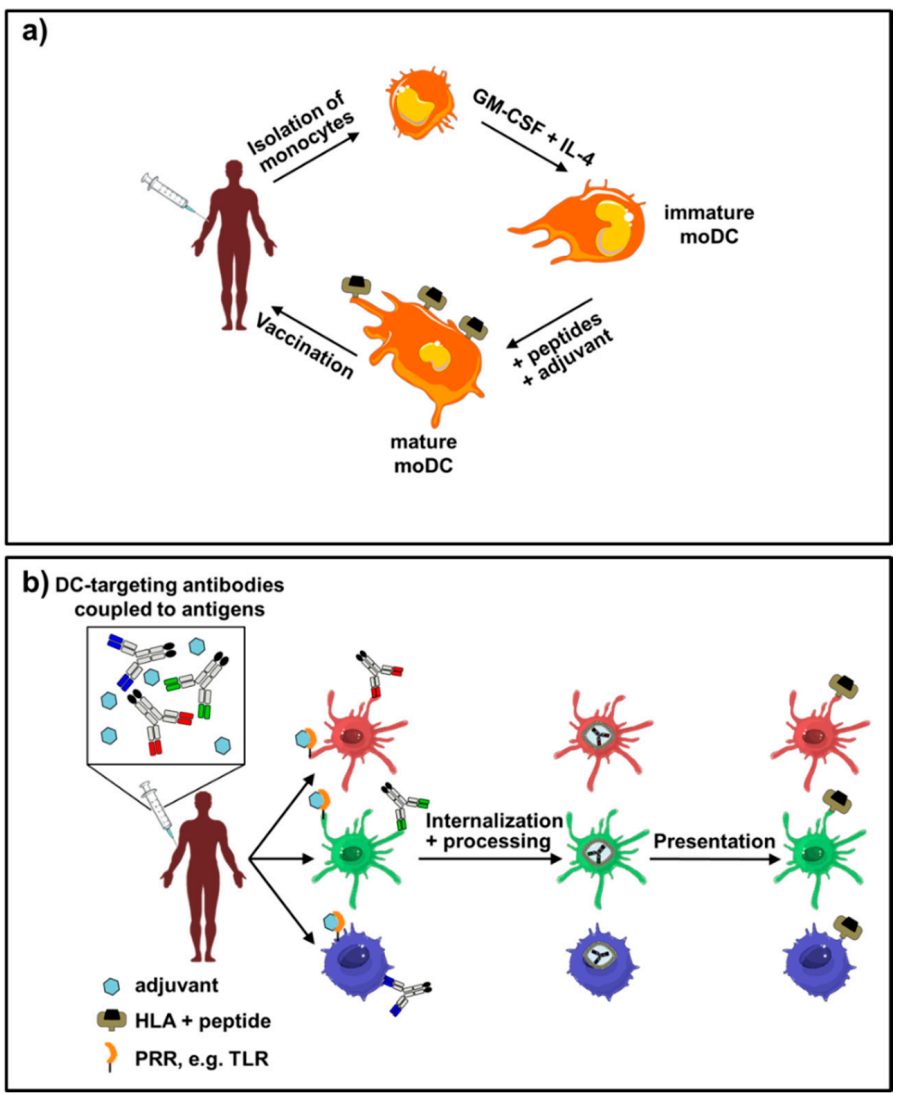

Figure 1. Principles of the use of human dendritic cells (DCs) for the treatment of diseases. There are two principal approaches to use DCs for the treatment of patients either by (a) using monocyte-derived DCs (moDCs) or by (b) directly targeting DCs in the patient using DC-targeting antibodies coupled to antigens. (a) For the vaccination of patients with their own moDCs, monocytes are isolated from the blood of the patient and differentiated into moDCs by culturing them in media containing GM-CSF and IL-4 for 5-6 days. Subsequently, cells are loaded with antigens and either matured with adjuvants (e.g., cytokine cocktail consisting of IL-1 $\beta, \mathrm{IL}-6, \mathrm{TNF} \alpha$, and $\mathrm{PGE}_{2}$ ) or kept immature. These cells presenting peptides of the antigen as peptide-MHC complexes on their surface are then transfused back into the patient to induce either an inflammatory $\mathrm{T}$ cell response (matured DCs) or tolerance (immature DCs); (b) in an alternative approach, antigens are targeted directly to DCs in vivo by fusion of the antigen to antibodies directed against DC surface molecules. After binding to the DCs, the antibodies are internalized, processed, and presented on MHC class I and II molecules on the DC surface. Analogous to moDCs, the DCs induce an inflammatory T cell response in the presence of adjuvants such as toll like receptor (TLR) ligands or tolerance, if the antibody is injected alone without adjuvant. By usage of antibodies directed against surface molecules selectively expressed on one DC subset (here differentially colored in red, green, and blue), the type of immune response can be further regulated due to different functions of the DC subsets. Templates from Servier Medical Art (www.servier.com) were used and adapted for this figure. 
In vitro differentiated moDCs share many similarities with primary DCs found in human peripheral blood, indicated by their potential to activate and differentiate naïve $\mathrm{T}$ cells into effector T cells [50]. This is especially effective, when they are matured with single maturation stimuli (e.g., $\alpha$ CD40 antibody, TLR ligands, including LPS, pIC, or CpG) or maturation cocktails (IL-1 $\beta$, PGE 2 , IL-6, TNF $\alpha$ ) [45,46,48,49,51-53]. In recent years, moDCs have been generated for self-vaccination of otherwise incurable tumor patients [54]. Importantly, the production of therapeutic moDCs needs to be conducted under good manufacturing practice (GMP) conditions, including their differentiation from blood monocytes. These cells are then loaded with antigenic peptides [42,51,54-57], soluble proteins [58], or tumor lysates [40,54,59-66], or by the transfection of tumor epitope-encoding mRNAs [54,67-73], DNAs [74-77], or whole tumor mRNA [40,54,78], accompanied by protocols ensuring a full DC maturation (Figure 1a). This maturation process seems to be a critical step in the production of therapeutic moDCs, as the appropriate time point and the maturation cocktail composition determine the efficiency of the peptide-loaded moDCs to migrate into the patients' lymph nodes [41,43,49,79-81]. Several studies have been initiated using moDCs in the treatment of (mostly) stage-4 melanoma, prostate, pancreatic, and breast cancer, as well as glioblastoma, where a significantly prolonged overall survival of those patients could be documented $[42,49,57-59,62,63,68,81-88]$. Although moDC-based therapies increased the life expectancy of certain types of formerly incurable cancer patients, the response rate is still lower than desired [38,54,56,57,59,64,68,80,81,86,88-92]. Of great interest, treatment with checkpoint inhibitors in combination with antigen-loaded moDCs might further increase the overall survival rate. Future clinical studies will be indispensable to clarify the efficacy of this new combinatorial therapeutic approach [93-95].

\section{Delivery of Antigens to DC Subsets by Usage of Recombinant Antibodies}

Besides therapeutic approaches utilizing moDCs, other approaches in tumor vaccination strategies have been considered in human trials and preclinical models [96], such as immunization with tumor peptides [97-102], tumor-derived DNA [103,104], glycan-modified tumor antigens [105], liposomes [106-108], or even by injection of whole tumor lysates [109-111]. As described before, antigens can be provided to DCs by various techniques such as RNA or DNA electroporation, injection of soluble proteins, nanoparticles, liposomes, or long peptides. However, not all of these techniques can be used to specifically address antigens to DCs directly in vivo. Also the delivery of antigenic peptides by loading DCs with long peptides is not DC or antigen-presenting cell (APC) specific and bears the risk of the unintentional induction of tolerance to pathogen-derived antigens [112]. The usage of undirected nanoparticles or liposomes most likely target highly phagocytically active macrophages rather than DCs. Therefore, a more DC-specific antigen delivery technique is required. In consideration of those less specific antigen delivery techniques, the idea arose that a selective delivery of antigens to antigen presenting cells in vivo would be favorable for a better immune response against the targeted antigen without unwanted spreading of antigens, the need of cell isolation, cell manipulation, or in vitro moDC generation $[9,43,44]$. The last three points seem to be of critical importance, as DCs are very sensitive to experimental manipulations demonstrated by immediate changes in the DC activation status and phenotype in culture systems, thus no longer reflecting their natural in vivo phenotype $[2,4,113]$. Moreover, the newest findings suggest that moDCs should be rather allocated to the family of monocytes than to DCs [50]. Especially, this last issue might be important to understand the difficulties observed with moDC-based therapies, as monocytes themselves are less efficient than DCs in the activation of T cells upon peptide MHC (pMHC) complex presentation [114]. Thus, a directed delivery of antigens to the APCs in the most appropriate tissue might harbor the possibility of a better specificity on the one hand, but also a broader therapeutic application as needed for the treatment of infectious diseases, cancer, and autoimmune diseases on the other hand.

A precise delivery of antigens into DCs in vivo requires knowledge on the expression of endocytic receptors and the targeted DC subset. Today, mainly two strategies for a specific transport of antigens to DCs in vivo are discussed. Both take advantage of the specific binding of an antibody to an endocytic 
receptor on the DC surface, ensuring the delivery of the cargo into the antigen-processing machinery (Figure 1b). However, these two approaches differ in the entities coupled to these antibodies. One possibility is to couple them to nanoparticles or to liposomes containing the antigen of choice, which has been thoroughly reviewed elsewhere [115-117]. The second strategy is also known as antibody mediated antigen targeting and will be discussed in more detail in this review (Figure 1b, Table 1). Besides its endocytic capacity, the chosen receptor should only be expressed on professional APCs, such as DCs. Otherwise the distribution of the antigen among many different cells might lead to tolerogenic reactions, e.g., the induction of regulatory T cells. For this purpose, endocytic receptors naturally detecting pathogens, such as $\mathrm{C}$ type lectin receptors, have emerged as promising targeting receptors.

Once an endocytic candidate receptor has been selected and antibodies have been generated and tested, the antigen of choice can be coupled to these specific antibodies. This coupling process can either be accomplished by chemical linking of the antibody to the antigen to be delivered, or by production of a recombinant antibody-antigen fusion construct. For the production of these recombinant fusion constructs, the variable regions of the parental antibody are cloned by conventional methods or by using a phage display library. There are several advantages in using recombinant antigen-coupled antibodies in comparison to chemically conjugated antibodies. One important fact is the knowledge of the exact number of antigen molecules coupled. Second, it is more feasible to control the endotoxin concentrations by using an antibody-antigen cloning strategy. Another major advance is the possibility to genetically modify the targeting antibodies. In this way it is possible to not only optimize the production of the antibody itself, but to also modify its host compatibility (by humanization), its solubility (by changing amino acid composition), its fixation of complement components (by changing the glycosylation sites), its binding to Fc receptors (by changing glycosylation or using Fab or $\mathrm{scF}_{\mathrm{v}} \mathrm{s}$ (single chain $\left.\mathrm{F}_{\mathrm{V}} \mathrm{s}\right)$ ), and finally also its dimerization tendencies [118-125]. These facts allow for commercial GMP-compatible upscaling of the production of an antigen targeting antibody. Another research tool might be to utilize biotinylated antibodies together with Streptavidin-coupled antigens as recently demonstrated [126].

\section{Antigen Targeting Receptors}

\subsection{Subsets}

Several distinct DC subsets have been described in lymphoid and non-lymphoid organs of mouse and man. Depending on their localization, their cell surface marker and transcription factor expression, as well as their migratory potential, DCs can be roughly distinguished into plasmacytoid DCs (pDCs) and conventional (classical) DCs. The latter can be further separated into resident and migratory DCs [11,50,127]. In mice, pDCs express low to absent levels of CD11c and MHC class II, but high levels of B220, Bst-2, and Siglec-H. Interestingly, CCR9 (CDw199) has become a marker for the distinction of CCR9 negative mature and CCR9 positive immature pDCs [128,129]. pDCs are able to produce high amounts of type I interferon upon virus encounter or TLR9 stimulation [130-136]. Despite this strong ability to boost the initiation of an immune response, the role of pDCs in antigen presentation is under current debate [21,137-146].

In contrast to $\mathrm{pDCs}$, murine conventional DCs are prone to present antigens to naïve CD4 ${ }^{+}$and $\mathrm{CD}^{+} \mathrm{T}$ cells. Resident conventional DCs are localized in lymphoid organs such as lymph nodes, spleen, or Peyer's patches and can be distinguished by the expression of CD11c and MHC class II in combination with CD8, CD11b, CD172a (SIRP $\alpha)$, and XCR1 into CD11c ${ }^{+}$MHC-II ${ }^{\text {hi }}$ CD11b CD8 $^{+} \mathrm{XCR}^{+}$ (further referred to as resident $\mathrm{CD} 8^{+} \mathrm{DCs}$ ) and $\mathrm{CD} 11 \mathrm{c}^{+} \mathrm{MHC}-\mathrm{II}^{\text {hi }} \mathrm{CD} 11 \mathrm{~b}^{+} \mathrm{CD} 8^{-} \mathrm{SIRP} \alpha^{+} \mathrm{DCs}$ (further referred to as resident CD8 ${ }^{-}$DCs) $[3,147,148]$. Non-lymphoid migratory DCs are localized in non-lymphoid tissues and can be distinguished by the expression of CD103, CD207, and CD11b, which is also true for skin DCs [11,127,149]. They are highly positive for MHC class II and are-especially after antigen uptake and maturation-able to migrate from their respective peripheral tissues into lymphoid tissues, preferentially into draining lymph nodes (e.g., dermal dendritic cells [148,150]). 
In humans, DCs can be distinguished into CD1c $\mathrm{C}^{+} \mathrm{DC}, \mathrm{CD} 141^{+} \mathrm{DC}$, and pDCs. The functional specialization of human DC subsets is under great debate and current knowledge has been reviewed elsewhere [151-156].

\subsection{Antigen Targeting to DCs and DC Subsets by Utilizing C Type Lectin Receptors}

The identification of endocytic receptors specifically expressed by certain DC subsets of mice and the generation of recombinant murine DC subset-specific antigen targeting antibodies made it possible to target antigens to single DC subsets in mice in vivo [3,8,157-160]. In this section, we focused on several important examples. However, due to space constraints we were unable to discuss all receptors and all studies using a specific receptor and have therefore included a table with a more comprehensive list of citations (Table 1).

The first proof-of-principle was provided by utilizing a specific $C$ type lectin receptor antibody for DEC205 (Ly-75, DEC-205, CD205). DEC205 is harboring 10 carbohydrate recognition domains and has a molecular weight of $205 \mathrm{kDa}$ [161]. This receptor was shown to be highly expressed on resident $\mathrm{CD}^{+}$DCs and thymic epithelial cells $[148,153,161]$. Some studies also propose a weak expression on B cells, T cells, and granulocytes [114,162-164]. Importantly, upon antigen encounter, mimicked by the usage of chimeric receptors, it has been demonstrated that DEC205 internalizes and recycles very efficiently via MHC-II positive cellular compartments back to the surface [165]. The natural ligand of DEC205 remains still to be found, but some studies suggest apoptotic and necrotic material as well as CpG motifs as consecutive ligands [166-168]. A recent study also suggested the plasminogen activator Pla of Yersinia pestis as a potential receptor ligand responsible for the bacterial dissemination [169]. Another C type lectin receptor, the Dendritic Cell Inhibitory Receptor 2 (DCIR2, antibody clone 33D1, Clec4A, CD367), is exclusively expressed by resident CD8 ${ }^{-}$splenic DCs in mice [3,170-172]. In humans, a relative of DCIR2 (DCIR) can be found on all blood DC subsets, monocytes, and granulocytes $[170,173,174]$. The natural ligand for DCIR has not yet been found, however there are studies suggesting a possible role in recognizing HIV glycoproteins [175-177]. Upon antibody binding to human DCIR, Meyer-Wentrup, et al. demonstrated that DCIR is internalized into endosomal/lysosomal compartments and was able to induce T cell responses [143]. 
Table 1. Overview of important antigen targeting studies.

\begin{tabular}{|c|c|c|c|c|c|c|}
\hline & $\begin{array}{l}\text { Targeted } \\
\text { Population }\end{array}$ & $\begin{array}{c}\text { Antibody } \\
\text { Type/Coupling }\end{array}$ & Used Antigen & In Vivo Model & Outcome & Ref. \\
\hline \multirow{15}{*}{ DEC205 } & \multirow{15}{*}{$\begin{array}{l}\text { Murine } \mathrm{CD} 8^{+} \\
\text {DEC205 } \\
\text { DCs }\end{array}$} & \multirow{15}{*}{$\begin{array}{l}\text { Fusion-protein, } \\
\text { no FcR-binding }\end{array}$} & \multirow{6}{*}{ ovalbumin } & Transfer of OT-I and OT-II transgenic T cells & $\begin{array}{l}\text { Strong cross-presentation by } \mathrm{CD} 8^{+} \text {DCs targeted with a DEC205 } \\
\text { antibody due to the expression of MHC-I machinery }\end{array}$ & [3] \\
\hline & & & & Transfer of DO11.10 transgenic T cells & TGF $\beta$-dependent induction of FoxP3 ${ }^{+} \mathrm{T}_{\text {regs }}$ & [7] \\
\hline & & & & Immunization of naïve C57Bl/ 6 mice & Induction of strong $\mathrm{CD} 8^{+}$and weaker $\mathrm{CD} 4^{+} \mathrm{T}$ cell responses & [178] \\
\hline & & & & Immunization of naïve C57Bl/ 6 mice & Ex vivo induced OT-I and OT-II T cell proliferation & [114] \\
\hline & & & & $\begin{array}{l}\text { Transfer of OT-II transgenic T cells into } \\
\text { BDCA-2 transgenic C57Bl/ } 6 \text { mice }\end{array}$ & $\mathrm{CD}^{+}{ }^{+} \mathrm{T}$ cell proliferation, differentiation, and humoral responses & [137] \\
\hline & & & & $\begin{array}{l}\text { Ova-expressing B16F10 melanoma cells, } \\
\text { protective and therapeutic model }\end{array}$ & $\begin{array}{l}\text { Induction of therapeutic and protective anti-tumor immune responses, } \\
\text { ova-specific } \mathrm{CD} 4^{+} \text {and } \mathrm{CD} 8^{+} \mathrm{T} \text { cell responses in naive } \mathrm{C} 57 \mathrm{Bl} / 6 \text { mice, } \\
\text { strong ova-specific mixed } \operatorname{IgG} 1 / \mathrm{IgG} 2 \mathrm{a} \text { antibody response }\end{array}$ & [179] \\
\hline & & & $\begin{array}{l}\text { ovalbumin/ova-NP, } \\
\text { circumsporozoite } \\
\text { protein (CSP) }\end{array}$ & $\begin{array}{l}\text { Immunization of naïve C57Bl/6, B10.BR, } \\
\text { and BALB/c mice; transfer of CSP } \\
\text { transgenic T cells }\end{array}$ & $\begin{array}{l}\text { Induction of Thelper cell responses, induction of high titers of } \\
\text { hapten-specific IgG, stronger antibody response in comparison to } \\
\text { immunization with irradiated sporozoites }\end{array}$ & [180] \\
\hline & & & ovalbumin/ $\alpha$-GalCer & $\begin{array}{l}\text { Ova-expressing B16F10 and EG7, transfer of } \\
\text { transgenic OT-I cells }\end{array}$ & $\begin{array}{l}\text { Delivery of ova and } \alpha \text {-GalCer to } \mathrm{CD} 8^{+} \mathrm{DCs} \text { induces iNKT cell, } \mathrm{CD} 8^{+} \\
\mathrm{T} \text { cell, and protective and therapeutic anti-tumor responses }\end{array}$ & [181] \\
\hline & & & LcrV & Lethal aerosol challenge with $Y$. pestis & $\begin{array}{l}\text { Induction of LcrV-specific antibody response, poorer survival in } \\
\text { comparison to targeting with DCIR2 }\end{array}$ & [182] \\
\hline & & & NS-1 (Dengue virus) & $\begin{array}{l}\text { Lethal intracranial challenge } \\
\text { with DENV2 NGC }\end{array}$ & $\begin{array}{l}\text { Improved survival by targeting NS-1 via DEC205 to CD } 8^{+} \mathrm{DCs} \text {, } \\
\text { stronger } \mathrm{T}_{\mathrm{H}} 1 \text { response and IFN } \gamma^{+} \mathrm{T} \text { cells }\end{array}$ & [171] \\
\hline & & & HIV gag p24 and p41 & Intranasal challenge with vaccinia-gag & $\begin{array}{l}\text { Strong and broad T cell and antibody response to HIV gag, reduced } \\
\text { severity of vaccinia-gag infection }\end{array}$ & [183] \\
\hline & & & \multirow{3}{*}{ HIV gag p24 } & Immunization of naïve $\mathrm{C} 57 \mathrm{Bl} / 6$ mice & Induction of IFN $\gamma^{+} \mathrm{CD} 4^{+}$and $\mathrm{CD} 8^{+} \mathrm{T}$ cell responses & [184] \\
\hline & & & & $\begin{array}{l}\text { Immunization of naïve mice in combination } \\
\text { with several adjuvants }\end{array}$ & $\begin{array}{l}\text { Poly(I:C) strongest adjuvant, signaling via IFNAR necessary for } \\
\text { activation of DCs and induction of CD8 } 8^{+} \mathrm{T} \text { cell response }\end{array}$ & [185] \\
\hline & & & & Immunization of naïve $\mathrm{C} 57 \mathrm{Bl} / 6$ mice & Long-term HIV-specific immunity within the gastrointestinal tract & [186] \\
\hline & & & $\begin{array}{l}\text { human cartilage } \\
\text { proteoglycan (PG) }\end{array}$ & $\begin{array}{l}\text { PG-induced arthritis with transfer of } \\
\text { transgenic PG-specific T cells }\end{array}$ & $\begin{array}{l}\text { Targeting PG to DCs induced reduced arthritis score, lower titer of } \\
\text { PG-specific IgG1 and IgG2a, and lower proliferation of } C D 4^{+} \mathrm{T} \text { cells }\end{array}$ & [187] \\
\hline
\end{tabular}


Table 1. Cont

\begin{tabular}{|c|c|c|c|c|c|c|}
\hline & $\begin{array}{l}\text { Targeted } \\
\text { Population }\end{array}$ & $\begin{array}{c}\text { Antibody } \\
\text { Type/Coupling }\end{array}$ & Used Antigen & In Vivo Model & Outcome & Ref. \\
\hline \multirow{14}{*}{ DEC205 } & \multirow{14}{*}{$\begin{array}{l}\text { Murine CD8 }{ }^{+} \\
\text {DEC205 }{ }^{+} \text {DCs }\end{array}$} & \multirow{10}{*}{$\begin{array}{l}\text { Fusion-protein, } \\
\text { no FcR-binding }\end{array}$} & $\begin{array}{l}\text { stress-inducible } 1 \\
\text { protein of L. major } \\
\quad(\text { LmSTI1a) }\end{array}$ & $\begin{array}{l}\text { Intradermal or subcutaneous challenge with } \\
\text { L. major }\end{array}$ & $\begin{array}{l}\text { Induction of IFN } \gamma^{+} \mathrm{CD} 4^{+} \mathrm{T} \text { cell responses, improved survival after } \\
\text { challenge with } L \text {. major in BALB/c mice }\end{array}$ & [188] \\
\hline & & & Her2/neu & $\begin{array}{l}\text { Protective breast cancer model, injection of } \\
\text { NT2.5 tumor cells into FVB } / \mathrm{N} \text { mice }\end{array}$ & $\begin{array}{l}\text { Induction of IFN } \gamma^{+} \mathrm{CD} 4^{+} \text {and } \mathrm{CD} 8^{+} \mathrm{T} \text { cell responses, protection in } \\
\text { a breast cancer tumor model }\end{array}$ & [189] \\
\hline & & & $\begin{array}{l}\text { Trypanosoma cruzi } \\
\text { amastigote surface } \\
\text { protein } 2 \text { (ASP-2) }\end{array}$ & Immunization of naïve $\mathrm{C} 57 \mathrm{Bl} / 6$ mice & $\begin{array}{l}\text { Induction of IFN } \gamma^{+} \mathrm{CD} 4^{+} \mathrm{T} \text { cells, identification of an immunogenic } \\
\text { epitope of ASP-2 }\end{array}$ & [190] \\
\hline & & & MimA2 & $\begin{array}{l}\text { Transfer of diabetogenic transgenic AI4 T } \\
\text { cells in NOD mice }\end{array}$ & $\begin{array}{l}\text { Induction of tolerance to MimA2 due to deletion of the } \\
\text { transferred T cells }\end{array}$ & [191] \\
\hline & & & $\begin{array}{l}\text { BDC2.5 mimitope } \\
\text { peptide } \\
\text { 1040-63/pro-Insulin }\end{array}$ & $\begin{array}{l}\text { Transfer of transgenic BDC2.5 T cells in } \\
\text { NOD mice }\end{array}$ & $\begin{array}{l}\text { Induction of } \mathrm{T}_{\text {reg }} \text { cells by delivery of BDC2.5 mimitope } \\
\text { via DEC205, delayed onset of diabetes by delivery of pro-insulin to } \\
\text { DCs via DEC205 }\end{array}$ & [192] \\
\hline & & & LACK (L. major) & Transfer of LACK-specific transgenic T cells & $\begin{array}{l}\text { Targeting DEC205 induces IFN } \gamma^{+} \mathrm{T}_{\mathrm{H}} 1 \text { cells independent of IL-12, but } \\
\text { dependent on CD70 }\end{array}$ & [160] \\
\hline & & & survivin & $\begin{array}{l}\text { Immunization of naïve mice, } \\
\text { depletion of } T_{\text {regs }}\end{array}$ & $\begin{array}{l}\text { Mainly specific } \mathrm{T} \text { cells against human survivin; depletion of } \mathrm{T}_{\text {regs }} \\
\text { enhances T cell response against survivin }\end{array}$ & [193] \\
\hline & & & IGRP & Immunization of naïve NOD mice & Reduced type-I diabetes & [194] \\
\hline & & & PLP(139-151) & $\begin{array}{l}\text { Immunization of SJL/J mice after transfer of } \\
5 B 6 \text { transgenic T cells }\end{array}$ & Reduced experimental autoimmune encephalomyelitis (EAE) & [195] \\
\hline & & & HEL & Transfer of $3 \mathrm{~A} 9$ transgenic $\mathrm{T}$ cells & $\begin{array}{l}\text { T cell tolerance in response to antibody alone, memory response after } \\
\text { co-injection of } \alpha \mathrm{CD} 40\end{array}$ & [8] \\
\hline & & $\begin{array}{l}\text { Fusion protein, } \\
\text { FcR-binding? }\end{array}$ & ovalbumin & Transfer of OT-I and OT-II transgenic T cells & $\begin{array}{l}\text { Even mature DCs take up antigens via targeting antibodies; induction } \\
\text { of OT-I and OT-II T cell activation and proliferation }\end{array}$ & [196] \\
\hline & & $\begin{array}{l}\text { Fusion-protein, } \\
\text { single chain Fv }\end{array}$ & $\begin{array}{c}\text { myelin } \\
\text { oligodendrocyte } \\
\text { glycoprotein (MOG) }\end{array}$ & $\begin{array}{l}\text { MOG-induced experimental allergic } \\
\text { encephalomyelitis (EAE) }\end{array}$ & $\begin{array}{l}\text { Induction of protective and therapeutic responses against EAE by } \\
\text { targeting MOG to } \mathrm{CD} 8^{+} \mathrm{DCs}\end{array}$ & [197] \\
\hline & & $\begin{array}{l}\text { Fusion-protein, } \\
\text { single chain Fv }\end{array}$ & $\begin{array}{l}\text { hNC16A collagen } \\
\text { domain }\end{array}$ & Immunization of naïve $\mathrm{C} 57 \mathrm{Bl} / 6$ mice & Reduced graft rejection & [198] \\
\hline & & Single chain Fv & $\begin{array}{l}\text { ova/Plasma } \\
\text { membrane vesicles of } \\
\text { B16F10-ova cells }\end{array}$ & $\begin{array}{l}\text { Vaccination with liposomes or plasma } \\
\text { membrane vesicles; i.v. injection of } \\
\text { B16F10-ova cells (Lung metastasis model) }\end{array}$ & $\begin{array}{l}\text { Antigen can be delivered in liposomes or plasma membrane vesicles } \\
\text { via coupled scFv against DEC205 to DCs; reduction of tumor growth } \\
\text { due to tumor-specific T cells }\end{array}$ & [199] \\
\hline
\end{tabular}


Table 1. Cont

\begin{tabular}{|c|c|c|c|c|c|c|}
\hline & $\begin{array}{l}\text { Targeted } \\
\text { Population }\end{array}$ & $\begin{array}{c}\text { Antibody } \\
\text { Type/Coupling }\end{array}$ & Used Antigen & In Vivo Model & Outcome & Ref. \\
\hline \multirow{11}{*}{ DEC205 } & $\begin{array}{c}\text { Murine } \\
\text { DEC205 } \\
\text { DCs, CD8 } \\
\text { DEC205 } \\
\text { spleen DCs } \\
\end{array}$ & $\begin{array}{l}\text { Chemically } \\
\text { coupled, } \\
\text { FcR-binding? }\end{array}$ & ovalbumin & $\begin{array}{l}\text { Transfer of OT-I and OT-II transgenic T cells; } \\
\text { challenge with MO4-ova and vaccinia-ova }\end{array}$ & $\begin{array}{l}\text { Induction of IFN } \gamma^{+} \text {memory } \mathrm{T} \text { cell responses; vaccination induces } \\
\text { protection against MO4-ova and vaccinia-ova; in vivo targeting } \\
\text { protects in contrast to ex vivo loaded DCs }\end{array}$ & [157] \\
\hline & $\begin{array}{l}\text { Murine } \\
\text { CD11c } c^{+} \text {LN } \\
\text { DCs }\end{array}$ & $\begin{array}{l}\text { Chemically } \\
\text { coupled, } \\
\text { FcR-binding? }\end{array}$ & ovalbumin & Transfer of OT-I transgenic T cells & $\begin{array}{l}\mathrm{T} \text { cell tolerance in response to antibody alone, memory response after } \\
\text { co-injection of } \alpha \mathrm{CD} 40\end{array}$ & [200] \\
\hline & $\begin{array}{l}\text { Murine } \\
\text { CD11c } \mathrm{c}^{+} \mathrm{DCs}\end{array}$ & $\begin{array}{l}\text { Chemically } \\
\text { coupled, } \\
\text { FcR-binding? }\end{array}$ & ovalbumin/TNCB & $\begin{array}{l}\text { Delayed-type hypersensitivity and contact } \\
\text { hypersensitivity model }\end{array}$ & Induction of $\mathrm{T}_{\text {regs }}$, tolerance in DTH and CHS models & [165] \\
\hline & $\begin{array}{l}\text { Murine } \\
\text { dermal and } \\
\text { LN DCs }\end{array}$ & $\begin{array}{l}\text { Fusion protein, } \\
\text { no FcR-binding }\end{array}$ & ovalbumin & Transfer of target cells in vaccinated mice & $\begin{array}{l}\alpha \mathrm{DEC} 205 \text { targets LCs and dermal DCs; induces cytotoxic CD8 } 8^{+} \mathrm{T} \text { cell } \\
\text { responses independent of Langerin }{ }^{+} \text {DCs (Langerin-DTR mice) }\end{array}$ & [201] \\
\hline & $\begin{array}{l}\text { Murine LCs } \\
\text { and dermal } \\
\text { DCs }\end{array}$ & $\begin{array}{l}\text { Fusion protein, } \\
\text { no FcR-binding }\end{array}$ & ovalbumin & Naïve C57Bl/6 mice & $\begin{array}{l}\text { LCs are targeted by both Langerin and DEC } 205 \text { antibodies; only } \\
\text { DEC205 induces CD } 4^{+} \text {and CD } 8^{+} \mathrm{T} \text { cell responses }\end{array}$ & [202] \\
\hline & DEC $205^{+}$DCs & $\begin{array}{l}\text { Fusion protein, } \\
\text { no FcR-binding }\end{array}$ & HIV gag p24 & Immunization of non-human primates & $\begin{array}{l}\text { Induction of broad CD } 4^{+} \text {and } \mathrm{CD} 8^{+} \mathrm{T} \text { cell responses against } \mathrm{p} 24 \text { after } \\
\text { targeting of DEC205 in combination with poly ICLC }\end{array}$ & [203] \\
\hline & Human DCs & $\begin{array}{c}\text { Fusion protein, } \\
\text { monoclonal } \\
\text { humanized } \\
\text { antibody }\end{array}$ & NY-ESO-1 & $\begin{array}{l}\text { Phase I trial with NY-ESO-1 } \\
\text { positive patients }\end{array}$ & $\begin{array}{l}13 / 45 \text { patients with stabilized disease, } 2 / 45 \text { with tumor regression; no } \\
\text { dose-limiting or grade } 3 \text { toxicities reported }\end{array}$ & [85] \\
\hline & $\begin{array}{c}\text { Human } \\
\text { moDCs, } \\
\text { DEC205 cells } \\
\text { in humanized } \\
\text { mice }\end{array}$ & $\begin{array}{l}\text { Fusion protein, } \\
\text { FcR-binding }\end{array}$ & EBNA-1 & Vaccination of humanized NOG mice & $\begin{array}{l}\text { Activation of EBNA-1 specific autologous T cells; protection against } \\
\text { EBV-infected B cells; induction of EBNA-1-specific T cells in } \\
\text { humanized mice }\end{array}$ & [204] \\
\hline & \multirow{3}{*}{$\begin{array}{l}\text { Human } \\
\text { moDCs }\end{array}$} & \multirow{2}{*}{$\begin{array}{l}\text { Fusion protein, } \\
\text { FcR-binding }\end{array}$} & HIV gag p24 & - & $\begin{array}{l}\text { Stronger IFN } \gamma^{+} \mathrm{CD} 8^{+} \mathrm{T} \text { cell responses by targeting with DEC205 in } \\
\text { comparison to DC-SIGN or MMR }\end{array}$ & [205] \\
\hline & & & NY-ESO-1 & - & $\begin{array}{l}\text { Induction of } \mathrm{CD}^{+}{ }^{+} \text {and } \mathrm{CD} 8^{+} \mathrm{T} \text { cell responses in PBMCs of NY-ESO-1 } \\
\text { seropositive breast cancer patients }\end{array}$ & [206] \\
\hline & & $\begin{array}{l}\text { Fusion protein, } \\
\text { single chain } \mathrm{Fv}\end{array}$ & MAGE-A3 epitope & - & Induction of proliferation of TCR-transfected $\mathrm{CD} 4^{+} \mathrm{T}$ cells & [207] \\
\hline
\end{tabular}


Table 1. Cont.

\begin{tabular}{|c|c|c|c|c|c|c|}
\hline & $\begin{array}{l}\text { Targeted } \\
\text { Population }\end{array}$ & $\begin{array}{c}\text { Antibody } \\
\text { Type/Coupling }\end{array}$ & Used Antigen & In Vivo Model & Outcome & Ref. \\
\hline \multirow{9}{*}{ DCIR2 } & \multirow{4}{*}{$\begin{array}{l}\text { Murine CD8 } \\
\text { DCIR2 }^{+} \text {DCs }\end{array}$} & \multirow{4}{*}{$\begin{array}{l}\text { Fusion-protein, } \\
\text { no FcR-binding }\end{array}$} & \multirow{4}{*}{ ovalbumin } & Transfer of OT-I and OT-II transgenic T cells & $\begin{array}{l}\text { Mainly } \mathrm{CD}^{+} \mathrm{T} \text { cell response, stronger expression of MHC-II } \\
\text { machinery in } \mathrm{CD} 8^{-} \mathrm{DCs}\end{array}$ & [3] \\
\hline & & & & $\begin{array}{l}\text { Ova-expressing B16F10 melanoma cells, } \\
\text { protective and therapeutic model }\end{array}$ & $\begin{array}{l}\text { Induction of therapeutic and protective anti-tumor immune responses, } \\
\text { ova-specific } \mathrm{CD} 4^{+} \text {and } \mathrm{CD} 8^{+} \mathrm{T} \text { cell responses in naive } \mathrm{C} 57 \mathrm{Bl} / 6 \text { mice, } \\
\text { strong ova-specific mixed IgG1/IgG2a antibody response }\end{array}$ & [179] \\
\hline & & & & Immunization of naïve $\mathrm{C} 57 \mathrm{Bl} / 6$ mice & Ex vivo induced OT-I and OT-II T cell proliferation & [114] \\
\hline & & & & Immunization of naïve C57Bl/6 mice & Induction of mainly $\mathrm{CD} 4^{+}$and weaker $\mathrm{CD} 8^{+} \mathrm{T}$ cell responses & [178] \\
\hline & $\begin{array}{l}\text { Murine } \\
\text { dermal and } \\
\text { LN DCs }\end{array}$ & $\begin{array}{l}\text { Fusion protein, } \\
\text { no FcR-binding }\end{array}$ & LcrV & Lethal aerosol challenge with Y. pestis & $\begin{array}{l}\text { Induction of LcrV-specific antibody response, improved survival after } \\
\text { targeting of DCIR2 }\end{array}$ & [182] \\
\hline & $\begin{array}{l}\text { Murine LCs } \\
\text { and dermal } \\
\text { DCs }\end{array}$ & $\begin{array}{l}\text { Fusion protein, } \\
\text { no FcR-binding }\end{array}$ & LACK (L. major) & Transfer of LACK-specific transgenic T cells & $\begin{array}{l}\text { Targeting DCIR2 induces IFN } \gamma^{+} \mathrm{T}_{\mathrm{H}} 1 \text { cells dependent on IL-12, but } \\
\text { independent of CD70 }\end{array}$ & [160] \\
\hline & DEC $205^{+} \mathrm{DCs}$ & $\begin{array}{l}\text { Chemically } \\
\text { coupled, } \\
\text { Fab-fragment }\end{array}$ & ovalbumin & $\begin{array}{l}\text { Immunization of naïve } \mathrm{C} 57 \mathrm{Bl} / 6 \text { and } \\
\mathrm{BALB} / \mathrm{c} \text { mice }\end{array}$ & Induction of antibody responses & [208] \\
\hline & $\begin{array}{c}\text { CD34 }^{+} \text {-derived } \\
\text { LCs, } \\
\text { epidermal } \\
\text { LCs, CD11c }{ }^{+} \\
\text {blood DCs, } \\
\text { blood pDCs }\end{array}$ & $\begin{array}{l}\text { Fusion protein, } \\
\text { no FcR-binding }\end{array}$ & $\begin{array}{l}\text { FluMP/MART-1/HIV } \\
\text { gag p } 24\end{array}$ & - & Induction of IFN $\gamma^{+} \mathrm{CD} 8^{+} \mathrm{T}$ cell responses & [174] \\
\hline & $\begin{array}{l}\text { Human blood } \\
\text { pDCs }\end{array}$ & $\begin{array}{l}\text { Chemically } \\
\text { coupled, } \\
\text { FcR-binding? }\end{array}$ & KLH & - & Proliferation of T cells (not further defined) & [143] \\
\hline \multirow{4}{*}{ Clec9a } & \multirow{4}{*}{$\begin{array}{l}\text { Murine } \mathrm{CD} 8^{+} \\
\quad \text { DCs }\end{array}$} & $\begin{array}{l}\text { Fusion protein, } \\
\text { no FcR-binding }\end{array}$ & HIV gag p24 & Immunization of naïve $\mathrm{C} 57 \mathrm{Bl} / 6$ mice & Induction of IFN $\gamma^{+} \mathrm{CD} 4^{+}$and $\mathrm{CD} 8^{+} \mathrm{T}$ cell responses & [184] \\
\hline & & \multirow{3}{*}{$\begin{array}{l}\text { Chemically } \\
\text { coupled, } \\
\text { FcR-binding? }\end{array}$} & $\begin{array}{l}\text { SIINFEKL/epitopes } \\
\text { of gp100, TRP-1, } \\
\text { TRP-2 }\end{array}$ & Challenge with B16-ova cells & Protective and therapeutic responses in B16-ova melanoma model & [209] \\
\hline & & & ova-peptide (323-339) & Transfer of OT-II cells in C57Bl/ 6 mice & $\begin{array}{l}\text { Differential polarization of naive } \mathrm{CD} 4^{+} \mathrm{T} \text { cells dependent on } \\
\text { the adjuvant }\end{array}$ & [210] \\
\hline & & & ovalbumin & Immunization of naïve mice & $\begin{array}{l}\text { Induction of antibody response without adjuvant and independent } \\
\text { of MyD88-signaling; induction of OT-I and OT-II transgenic } \\
\text { T cell proliferation }\end{array}$ & [211] \\
\hline
\end{tabular}


Table 1. Cont

\begin{tabular}{|c|c|c|c|c|c|c|}
\hline & $\begin{array}{l}\text { Targeted } \\
\text { Population }\end{array}$ & $\begin{array}{c}\text { Antibody } \\
\text { Type/Coupling }\end{array}$ & Used Antigen & In Vivo Model & Outcome & Ref. \\
\hline & $\begin{array}{l}\text { Murine } \mathrm{CD} 8^{+} \\
\text {DCs }\end{array}$ & $\begin{array}{l}\text { Fusion protein, } \\
\text { single chain } \mathrm{Fv}_{\mathrm{v}}\end{array}$ & ovalbumin & Transfer of OT-I and OT-II cells & $\begin{array}{l}\text { Comparable OT-I T cell activation between DEC205 and Clec9a, } \\
\text { superior CD4 } 4^{+} \mathrm{T} \text { cell responses after targeting of Clec } 9 \mathrm{a}\end{array}$ & [212] \\
\hline & $\begin{array}{l}\text { Human blood } \\
\text { BDCA-3 } 3^{+} \text {DCs }\end{array}$ & $\begin{array}{l}\text { Biotin-labeled } \\
\text { KLH, gp110-filled } \\
\text { nanoparticles, } \\
\text { FcR-binding? }\end{array}$ & KLH/gp100 & - & $\begin{array}{l}\text { Induction of } \mathrm{KLH}^{+} \mathrm{CD} 4^{+} \mathrm{T} \text { cell responses, cross-presentation to } \mathrm{CD} 8^{+} \\
\mathrm{T} \text { cells }\end{array}$ & [213] \\
\hline Clec12a & $\begin{array}{l}\text { Murine } \mathrm{CD} 8^{+} \\
\text {DCs and } \\
\text { pDCs }\end{array}$ & $\begin{array}{l}\text { Chemically } \\
\text { coupled, } \\
\text { FcR-binding? }\end{array}$ & ovalbumin & $\begin{array}{l}\text { Transfer of OT-I and OT-II cells in C57Bl/ } 6 \\
\text { and CD11c-DTR mice }\end{array}$ & Induction of OT-I and OT-II responses by CD11c cells & [214] \\
\hline \multirow{3}{*}{ Dectin-1 } & $\begin{array}{l}\text { Murine DN } \\
\text { DCs }\end{array}$ & $\begin{array}{l}\text { Chemically } \\
\text { coupled, } \\
\text { FcR-binding? }\end{array}$ & ovalbumin & $\begin{array}{l}\text { Immunization of naïve } \mathrm{C} 57 \mathrm{Bl} / 6 \text { mice, } \\
\text { transfer of OT-I and OT-II transgenic T cells }\end{array}$ & $\begin{array}{l}\text { Stronger } \mathrm{CD} 4^{+} \mathrm{T} \text { cell response and weaker } \mathrm{CD} 8^{+} \mathrm{T} \text { cell response in } \\
\text { comparison to DEC205-targeting; induction of strong antibody } \\
\text { response, especially after i.v. injection }\end{array}$ & [215] \\
\hline & $\begin{array}{l}\text { Human IFN } \alpha \\
\text { moDCs }\end{array}$ & $\begin{array}{l}\text { Fusion protein, } \\
\text { FcR-binding? }\end{array}$ & hemagglutinin & - & Re-stimulation of memory $\mathrm{T}_{\mathrm{H}} 17$ cells via antigen-targeting to Dectin- 1 & [216] \\
\hline & $\begin{array}{l}\text { Human IL-4 } \\
\text { or IFN } \gamma \text { DCs }\end{array}$ & Fusion to hIgG4 & $\begin{array}{l}\text { Flu M1, MART-1 } \\
\qquad(26-35)\end{array}$ & - & $\begin{array}{l}\text { Activation of moDCs by Dectin- } 1 \text { antibody, expansion of Flu M1 spec } \\
\& \text { MART- } 1 \text { CD } 8^{+} \mathrm{T} \text { cells, differentiation of naïve } \mathrm{CD} 8^{+} \mathrm{T} \text { cells into Flu } \\
\text { M1-specific }\end{array}$ & [217] \\
\hline \multirow{5}{*}{ Langerin } & $\begin{array}{l}\text { Murine CD8 } 8^{+} \\
\text {DEC205 }{ }^{+} \text {DCs }\end{array}$ & $\begin{array}{l}\text { Fusion-protein, } \\
\text { no FcR-binding }\end{array}$ & HIV gag p24 & Immunization of naïve $\mathrm{C} 57 \mathrm{Bl} / 6$ mice & Induction of IFN $\gamma^{+} \mathrm{CD} 4^{+}$and $\mathrm{CD} 8^{+} \mathrm{T}$ cell responses & [184] \\
\hline & $\begin{array}{l}\text { Murine } \\
\text { CD11c }^{+} \\
\text {Langerin }^{+} \\
\text {DCs }\end{array}$ & $\begin{array}{l}\text { Fusion-protein, } \\
\text { no FcR-binding }\end{array}$ & ovalbumin & Immunization of naïve $\mathrm{C} 57 \mathrm{Bl} / 6$ mice & Induction of $\mathrm{CD}^{+}$and $\mathrm{CD} 8^{+} \mathrm{T}$ cell responses & [178] \\
\hline & \multirow{2}{*}{$\begin{array}{l}\text { Murine LCs } \\
\text { and dermal } \\
\text { DCs }\end{array}$} & \multirow[t]{2}{*}{$\begin{array}{l}\text { Fusion-protein, } \\
\text { no FcR-binding }\end{array}$} & \multirow[t]{2}{*}{ ovalbumin } & B16-ova model & $\begin{array}{l}\text { Targeting of LCs with Langerin and Imiquimod led to cross-tolerance } \\
\text { and impaired secondary memory response using DEC } 205 \text { as targeting } \\
\text { antibody }\end{array}$ & [218] \\
\hline & & & & Naïve C57Bl/ 6 mice & $\begin{array}{l}\text { LCs are targeted by both Langerin and DEC } 205 \text { antibodies; only } \\
\text { DEC205 induces CD } 4^{+} \text {and CD } 8^{+} T \text { cell responses }\end{array}$ & [202] \\
\hline & $\begin{array}{l}\text { Murine LCs } \\
\text { and dermal } \\
\text { DCs }\end{array}$ & $\begin{array}{l}\text { Fusion-protein, } \\
\text { no FcR-binding }\end{array}$ & MOGp & $\begin{array}{l}\text { Naïve C } 57 \mathrm{Bl} / 6 \text { mice, partly transfer of } \\
\text { MOG-specific T cells }\end{array}$ & Langerin $^{+}$cells can induce tolerance in vivo & [172] \\
\hline
\end{tabular}


Table 1. Cont

\begin{tabular}{|c|c|c|c|c|c|c|}
\hline & $\begin{array}{l}\text { Targeted } \\
\text { Population }\end{array}$ & $\begin{array}{c}\text { Antibody } \\
\text { Type/Coupling }\end{array}$ & Used Antigen & In Vivo Model & Outcome & Ref. \\
\hline \multirow{5}{*}{ DC-SIGN } & $\begin{array}{l}\text { Human } \\
\text { moDCs }\end{array}$ & $\begin{array}{l}\text { Chemically } \\
\text { coupled, } \\
\text { FcR-binding? }\end{array}$ & KLH & - & Proliferation of T cells & {$[219]$} \\
\hline & \multirow{2}{*}{$\begin{array}{c}\text { Murine } \\
\text { CD11c cells } \\
\text { expressing } \\
\text { hDC-SIGN }\end{array}$} & \multirow{2}{*}{$\begin{array}{l}\text { Chemically } \\
\text { coupled, } \\
\text { FcR-binding? }\end{array}$} & \multirow[t]{2}{*}{ ovalbumin } & $\begin{array}{l}\text { Infection of humanized mice with Listeria } \\
\text { monocytogenes }\end{array}$ & $\begin{array}{l}\text { Vaccination with DC-SIGN-ova protects humanized mice from } \\
\text { infection with Listeria monocytogenes }\end{array}$ & {$[220]$} \\
\hline & & & & $\begin{array}{l}\text { Transfer of OT-I T cells into hDC-SIGN } \\
\text { expressing C57Bl/ } 6 \text { mice }\end{array}$ & $\begin{array}{l}\text { Prolonged antigen residence in early endosomes, delayed lysosomal } \\
\text { degradation, and cross-presentation }\end{array}$ & {$[221]$} \\
\hline & $\begin{array}{l}\text { DC-SIGN }{ }^{+} \\
\text {APCs }\end{array}$ & - & - & Injection of cynomolgus macaque & APCs in LNs of macaques were targeted & {$[222]$} \\
\hline & $\begin{array}{l}\text { Human } \\
\text { DC-SIGN } \\
\text { cells }\end{array}$ & $\begin{array}{l}\text { Chemically } \\
\text { coupled (KLH), } \\
\text { FcR-binding?; } \\
\text { fused scFv } \\
\text { (tetanus toxoid } \\
\text { peptides) }\end{array}$ & $\begin{array}{l}\mathrm{KLH} / \text { tetanus toxoid } \\
\text { peptides }\end{array}$ & Immunization of humanized mice & $\begin{array}{l}\text { Induction of cell proliferation after targeting of KLH to DC-SIGN }{ }^{+} \\
\text {cells; protection after transfer of Raji-cells }\end{array}$ & {$[223]$} \\
\hline \multirow{4}{*}{ MR } & \multirow{4}{*}{$\begin{array}{l}\text { Human } \\
\text { moDCs }\end{array}$} & \multirow{4}{*}{$\begin{array}{l}\text { Fusion-protein, } \\
\text { FcR-binding? }\end{array}$} & $\begin{array}{c}\text { chorionic } \\
\text { gonadotropin } \beta\end{array}$ & - & $\begin{array}{l}\text { Induction of autologous T cell responses against CG } \beta \text {; cytotoxic T cells } \\
\text { show lysis against CG } \beta^{+} \text {tumor cell lines (HLA-partially matched) }\end{array}$ & {$[224]$} \\
\hline & & & pmel17 & - & $\begin{array}{l}\text { Induction of autologous } \mathrm{T} \text { cell responses against pmel17; cytotoxic } \mathrm{T} \\
\text { cells show lysis against pmel17 } 7^{+} \text {melanoma cell lines (HLA-partially } \\
\text { matched) }\end{array}$ & {$[225]$} \\
\hline & & & $\begin{array}{c}\text { chorionic } \\
\text { gonadotropin } \beta\end{array}$ & - & $\begin{array}{l}\text { TLR ligands boosted cytotoxic } \mathrm{T} \text { cell response induced by antibody } \\
\text { targeting }\end{array}$ & {$[226]$} \\
\hline & & & NY-ESO-1 & - & Antigen targeting to MR induces activation of $\mathrm{CD} 4^{+}$and $\mathrm{CD} 8^{+} \mathrm{T}$ cells & {$[206$} \\
\hline \multirow{4}{*}{ CD11c } & \multirow{3}{*}{$\begin{array}{l}\text { Murine } \\
\text { CD11c cells }\end{array}$} & \multirow{2}{*}{$\begin{array}{l}\text { Chemically } \\
\text { coupled, } \\
\text { Fab-fragment }\end{array}$} & ovalbumin & $\begin{array}{l}\text { Immunization of naïve mice; transferof OT-I } \\
\text { and OT-II transgenic T cells; EL4 as target } \\
\text { cells }\end{array}$ & $\begin{array}{l}\mathrm{CD} 11 \mathrm{c} \text { superior in the generation of } \mathrm{CD} 8^{+} \text {and } \mathrm{CD} 4^{+} \mathrm{T} \text { cells; targeting } \\
\text { leads to in vivo lysis of EL4 cells; induces endogenous ova-specific T } \\
\text { cells }\end{array}$ & {$[227]$} \\
\hline & & & & $\begin{array}{l}\text { Immunization of naïve } \mathrm{C} 57 \mathrm{Bl} / 6 \text { and } \\
\mathrm{BALB} / \mathrm{c} \text { mice }\end{array}$ & Induction of antibody responses & {$[208]$} \\
\hline & & $\begin{array}{l}\text { Fusion protein, } \\
\text { single chain } \mathrm{Fv}\end{array}$ & Her2/neu & $\begin{array}{l}\text { Challenge with D2F2/E2 breast cancer cells; } \\
\text { spontaneous breast cancer model }\end{array}$ & $\begin{array}{l}\text { Induces protective and therapeutic immune responses against } \\
\text { Her } 2 / \text { neu expressing tumor cells; delays tumor growth and onset in a } \\
\text { spontaneous breast cancer model }\end{array}$ & {$[228]$} \\
\hline & $\begin{array}{l}\text { MHC-II }^{+} \\
\text {APCs }\end{array}$ & $\begin{array}{l}\text { Chemically } \\
\text { coupled, } \\
\text { Fab-fragment }\end{array}$ & ovalbumin & $\begin{array}{l}\text { Immunization of naïve } \mathrm{C} 57 \mathrm{Bl} / 6 \text { and } \\
\mathrm{BALB} / \mathrm{c} \text { mice }\end{array}$ & Induction of antibody responses & {$[208]$} \\
\hline
\end{tabular}


Table 1. Cont

\begin{tabular}{|c|c|c|c|c|c|c|}
\hline & $\begin{array}{c}\text { Targeted } \\
\text { Population }\end{array}$ & $\begin{array}{c}\text { Antibody } \\
\text { Type/Coupling }\end{array}$ & Used Antigen & In Vivo Model & Outcome & Ref \\
\hline \multirow{2}{*}{ MHC-II } & \multirow{2}{*}{$\begin{array}{l}\text { MHC-II }^{+} \\
\text {APCs }\end{array}$} & $\begin{array}{l}\text { Chemically } \\
\text { coupled, } \\
\text { Fab-fragment }\end{array}$ & ovalbumin & $\begin{array}{l}\text { Immunization of naïve } \mathrm{C} 57 \mathrm{Bl} / 6 \text { and } \\
\mathrm{BALB} / \mathrm{c} \text { mice }\end{array}$ & Induction of antibody responses & {$[208$} \\
\hline & & $\begin{array}{c}\text { Chemically } \\
\text { coupled, } \\
\text { superantigen M1 }\end{array}$ & ovalbumin & $\begin{array}{l}\text { In vivo killing assays; challenge with } \\
\text { B16F10-ova melanoma cells }\end{array}$ & $\begin{array}{l}\text { Cross-presentation by all splenic DC subsets; induces T cell responses } \\
\text { with in vivo killing activity; therapeutic response in B16F10-ova } \\
\text { melanoma model }\end{array}$ & {$[229$} \\
\hline \multirow{3}{*}{ LOX-1 } & $\begin{array}{l}\text { Not further } \\
\text { defined APCs } \\
\text { in vivo }\end{array}$ & $\begin{array}{l}\text { Chemically } \\
\text { coupled, } \\
\text { FcR-binding? }\end{array}$ & ovalbumin & $\begin{array}{l}\text { Challenge of C } 57 \mathrm{Bl} / 6 \text { mice with E.G7 tumor } \\
\text { cells expressing ova }\end{array}$ & $\begin{array}{l}\text { Targeting ova to LOX-1 induces protective immune response against } \\
\text { E.G7 cells }\end{array}$ & {$[230$} \\
\hline & $\begin{array}{c}\text { Macaque } \\
\text { blood CD11c } \\
\text { and CD14 } \\
\text { cells }\end{array}$ & $\begin{array}{l}\text { Fusion protein, } \\
\text { FcR-binding? }\end{array}$ & hemagglutinin & $\begin{array}{l}\text { Immunization of rhesus macaques; } \\
\text { challenge of macaques with Influenza }\end{array}$ & $\begin{array}{l}\text { Induction of HA-specific antibodies in macaques, higher antibody } \\
\text { titer in comparison of Dectin-1 targeting }\end{array}$ & {$[231$} \\
\hline & $\begin{array}{l}\text { Human IFN } \alpha \\
\text { moDCs }\end{array}$ & $\begin{array}{l}\text { Fusion protein, } \\
\text { FcR-binding? }\end{array}$ & hemagglutinin & - & LOX-1 targeting induces activation of $\mathrm{T}_{\mathrm{H}} 1$ cells & {$[232$} \\
\hline DC-ASGPR & $\begin{array}{l}\text { Human IFN } \alpha \\
\text { moDCs }\end{array}$ & $\begin{array}{l}\text { Fusion protein, } \\
\text { FcR-binding? }\end{array}$ & hemagglutinin & - & $\begin{array}{l}\text { DC-ASGPR targeting induces the secretion of IL-10 by DCs and the } \\
\text { polarization/re-stimulation of suppressive IL- } 10^{+} \mathrm{T} \text { cells }\end{array}$ & {$[232$} \\
\hline CD36 & $\begin{array}{l}\text { Murine } \mathrm{CD}^{+} \\
\text {DCs }\end{array}$ & $\begin{array}{l}\text { Fusion protein, } \\
\text { scFV }\end{array}$ & ovalbumin & $\begin{array}{l}\text { Challenge of C57Bl/ } 6 \text { mice with E.G7 tumor } \\
\text { cells expressing ova }\end{array}$ & $\begin{array}{l}\text { Targeting ova to CD36 induces protective immune response } \\
\text { against EG7 tumor cells expressing ova, memory OT-I T cell response } \\
\text { without adjuvant }\end{array}$ & {$[233$} \\
\hline \multirow{3}{*}{ Siglec-H } & \multirow{2}{*}{$\begin{array}{l}\text { Murine } \\
\text { plasmacytoid } \\
\text { DCs }\end{array}$} & \multirow[t]{2}{*}{$\begin{array}{l}\text { Fusion protein, } \\
\text { no FcR-binding }\end{array}$} & $\begin{array}{l}\text { ovalbumin, pHEL, } \\
\text { pMOG }\end{array}$ & EAE & $\begin{array}{l}\text { Less severe EAE after targeting of MOG to Siglec-H on pDCs, } \\
\text { less T cell polarization, lower antibody titers even after injection } \\
\text { of an adjuvant }\end{array}$ & {$[141$} \\
\hline & & & ovalbumin & $\begin{array}{l}\text { Transfer of OT-II transgenic T cells into } \\
\text { BDCA-2 transgenic C57Bl/ } 6 \text { mice }\end{array}$ & $\mathrm{CD}^{+} \mathrm{T}$ cell proliferation, differentiation, and humoral responses & {$[137$} \\
\hline & Murine pDCs & $\begin{array}{l}\text { Chemically } \\
\text { coupled, } \\
\text { FcR-binding? }\end{array}$ & ovalbumin & $\begin{array}{l}\text { Immunization of naïve mice, boost with } \\
\text { Vaccinia virus expressing ova }\end{array}$ & $\begin{array}{l}\text { Targeting ova via Siglec-H to pDCs induces ova-specific } \mathrm{CD} 8^{+} \mathrm{T} \text { cells } \\
\text { only when } \mathrm{CpG} \text { is co-injected }\end{array}$ & {$[234$} \\
\hline \multirow[t]{2}{*}{ BST-2 } & \multirow[t]{2}{*}{ Murine pDCs } & $\begin{array}{l}\text { Fusion protein, } \\
\text { no FcR-binding }\end{array}$ & ovalbumin, pHEL & $\begin{array}{l}\text { Vaccinia virus expressing ova, B16F10-ova } \\
\text { melanoma cells }\end{array}$ & $\begin{array}{l}\text { Targeting ova to pDCs via BST-2 protects against VV-infection and } \\
\text { B16F10-ova cells; induces activation of OT-I and OT-II cells } \\
\text { as well as antibody titer }\end{array}$ & {$[142$} \\
\hline & & $\begin{array}{l}\text { Chemically } \\
\text { coupled, } \\
\text { F(ab)2-fragment }\end{array}$ & ovalbumin & Transfer of OT-I and OT-II cells & $\begin{array}{l}\text { Targeting of ova to pDCs induces OT-II cell proliferation in lymph } \\
\text { nodes but not in spleen }\end{array}$ & {$[235$} \\
\hline BDCA-2 & Murine pDCs & $\begin{array}{l}\text { Fusion protein, } \\
\text { no FcR-binding }\end{array}$ & ovalbumin & $\begin{array}{l}\text { Transfer of OT-II transgenic T cells into } \\
\text { BDCA-2 transgenic C57Bl/6 mice }\end{array}$ & $\mathrm{CD}^{+} \mathrm{T}$ cell proliferation, differentiation, and humoral responses & {$[137$} \\
\hline
\end{tabular}


As the receptors DEC205 and DCIR2 have often been used in comparative studies, we summarized these results in the following section. By in vivo antigen targeting of murine resident CD8 ${ }^{-} \mathrm{DCs}$ in comparison to targeting of CD8 ${ }^{+}$DCs with antigen-carrying DCIR2 (33D1) or DEC205 antibodies, it became possible to preferentially induce either $\mathrm{CD}^{+}$or $\mathrm{CD}^{+} \mathrm{T}$ cell responses in vivo, respectively [3]. These experiments indicated that targeting $\mathrm{CD} 8^{+} \mathrm{DC}$ s is an efficient way to induce cross-presentation, whereas targeting of $C D 8^{-}$DCs is superior for processing and presentation of antigens through the traditional MHC class II pathway. The findings further suggested that this was not due to the receptor that was targeted, but rather due to an intrinsic difference in the MHC presentation capacities of the DC subsets under steady-state conditions [3,7,8,157,200].

Subsequent studies demonstrated that antigen targeting via the DEC205 or the DCIR2 receptor does not only lead to an expansion of transferred antigen-specific T cells in the beginning, but also to their depletion after several days. This was indicated by experiments, in which low doses of antibodies were administrated in the absence of co-stimulatory stimuli leading to the induction of peripheral tolerance under the control of regulatory $\mathrm{T}$ cells. These regulatory responses were very efficient as mice were protected from type 1 diabetes, experimental autoimmune arthritis, and experimental autoimmune encephalomyelitis (EAE) [3,7,8,157,187,191,194,195,197,198,200,236].

It was also shown that DEC205 or DCIR2 antibodies can be utilized under immunostimulatory conditions to induce protective cellular and humoral responses in vivo needed for the fight against pathogens and malignancies [3,170,179,180,182]. This has, for example, been shown for Yersenia pestis [182], Plasmodium yoelii [180], dengue virus [171], HIV [183,237], the cancer/testis antigen 1A (known as CTAG1A or NY-ESO-1), or the Her2/neu breast cancer antigen in a protective model with NT2.5 tumor cells [189]. Interestingly, Neubert, et al. could demonstrate the induction of both protective and therapeutic anti-tumor responses in a murine melanoma model, which was independent of the initially targeted DC subset [179].

Furthermore, other receptors, mainly belonging to the $C$ type lectin family, and their corresponding antibodies have been used for the induction of immune responses against various pathogens and cancer types in vivo. Here, we will present the most prominent studies in closer detail.

Human DC-specific intercellular adhesion molecule 3-grabbing non-integrin (DC-SIGN, Clec4L, CD209) has been demonstrated to recognize a variety of sugar residues including mannose residues on HIV virus particles. DC-SIGN is naturally expressed on moDCs, macrophages, and liver epithelial cells [238-240]. Importantly, a true homologue of human DC-SIGN has not been identified in mice yet, thus making it difficult to dissect functional aspects of DC-SIGN in vivo. The nearest homologues regarding ligand specificity are SIGN-R1 and SIGN-R3, which are both members of a family of eight different SIGN-Rs [241-243]. However, it has also become evident that the underlying signaling cascades differ in mice and humans [241]. To better understand, whether DC-SIGN might be useful for the delivery of antigens in humans, an interesting mouse model was generated expressing the human DC-SIGN molecule under the control of the CD11c promoter [244]. Although utilizing the CD11c promoter, which is not selectively active in DCs, might not be the best choice, the authors found the uptake of antigens via the DC-SIGN receptor to mainly induce Th2 immunity and regulatory responses $[29,245]$. Others observed potent $\mathrm{CD}^{+}$and $\mathrm{CD}^{+} \mathrm{T}$ cell responses in vivo and in vitro [219-221,232]. In a primate model with Macacca fascicularis it could also be shown that antigen targeting antibodies directed against macaque DC-SIGN were uptaken into myeloid APCs and Kupffer cells of the liver [222].

The member 9A of the $\mathrm{C}$ type lectin family (Clec9A, DNGR-1, CD370) is highly expressed on conventional $\mathrm{CD}^{+}$or $\mathrm{CD} 103^{+} \mathrm{DC}$ and their precursors, but also weakly on pDCs in mice. In humans, Clec9A expression was found on CD103+ intestinal and CD141+ DCs [209,211,246-251]. Studies using targeting antibodies coupled with the model antigen ovalbumin showed the generation of potent cytotoxic $\mathrm{CD}^{+} \mathrm{T}$ cell responses and the reduction of tumor load in an intravenous injection model of the pseudo-metastasing ovalbumin expressing melanoma cells [209]. Additionally, it has been demonstrated that this strategy is also suitable for eliciting $\mathrm{CD}^{+} \mathrm{T}$ cell as well as antibody 
responses [210-212]. Importantly, the phenotype of the differentiated T cells is completely dependent on the applied adjuvant and antibody dosage. In more detail, the injection under non-inflammatory conditions led to the generation of a regulatory $\mathrm{T}$ cell response. Interestingly, in dependency of the administered adjuvant, the co-injection with poly(I:C) induced Th1 responses, while co-administration of Curdlan elicited Th17 responses [210]. Another not further investigated finding is that targeting of Clec9A seems to be especially suitable for the differentiation of naïve $\mathrm{CD}^{+} \mathrm{T}$ cells into follicular $\mathrm{T}$ helper cells $\left(\mathrm{Bcl6}^{+} \mathrm{CXCR} 5^{+} \mathrm{PD}-1^{+} \mathrm{CH} 2 \mathrm{D} 1 \mathrm{~A}^{+} \mathrm{IL}-21^{+} \mathrm{ICOS}^{+}\right)$[212]. However, the mechanism of this process is not clear yet.

The macrophage mannose receptor (MMR, recently also MR, Clec13D, CD206) is not only expressed on macrophages, endothelial cells, and smooth muscle cells of the trachea, but also on mature and immature moDCs and on human peripheral blood CD1c ${ }^{+}$DCs in vivo [206,252,253]. Studies taking advantage of MMR-specific antibodies coupled to tumor antigens, such as pmel17 (pre-melanosome protein 17, also known as gp100) and hCG- $\beta$ (human chorionic gonadotropin $\beta$ ) induced an MHC-I and MHC-II presentation and an antigen-specific T cell proliferation [224-226]. Another study focused on the tumor antigen NY-ESO1, which was similarly coupled to an MMR antibody. Here, the authors demonstrated a pronounced $\mathrm{CD}^{+}$cytotoxic $\mathrm{T}$ cell response [206] suggesting that the chosen antigen might influence the resulting immune response.

The lectin-like oxidized low-density lipoproteine receptor 1 (LOX-1, Clec8A) is a receptor for heat-shock proteins (e.g., Hsp70 [230]) and apoptotic cellular fragments. It is an important player in immunological reactions to these proteins and apoptotic material and is also expressed on DCs [230,232]. The potency of LOX-1 was first demonstrated by targeting of the model antigen ovalbumin via a recombinant antibody to LOX-1. Interestingly, the authors found that the induced immune responses led to a rejection of the ectopically ovalbumin expressing lymphoma cell line E.G7 in vivo [230,232]. The analyses of antigen-specific $\mathrm{CD}^{+} \mathrm{T}$ cell responses revealed cytokine secretion of IL-2, IFN $\gamma$, and TNF $\alpha$ when the T cells were re-stimulated with antigen loaded bone marrow derived DCs (BMDCs) [230]. Recently, LOX-1 antigen targeting was approved for a study in rhesus macaques, in which the induction of influenza virus neutralizing antibodies was demonstrated after administration of hemagglutinin coupled LOX-1-specific targeting antibodies in vivo [231].

A further interesting targeting molecule is the ITAM-containing receptor Dectin-1, also known as Clec7A. Dectin-1 can bind $\beta$-glucans and is therefore important for the uptake of yeast and yeast-derived particles (Zymosan). The molecule is reported to be expressed on murine cDCs, Langerhans' cells (LCs), and in lower amounts also on murine pDCs [17,18,254,255]. In humans Dectin-1 can be found on all monocyte populations as well as macrophages, DCs, neutrophils, B cells, and eosinophils $[17,18,256]$. Data demonstrated that in macrophages the endocytosis via Dectin-1 is independent of Syk activity, while ligand recognition in murine DCs triggers Syk and CARD9 activation [257]. This results in the transcription of innate immune response genes [258]. Notably, Dectin-1 can shuffle bound soluble proteins into the cell, while the receptor recycles back to the cell surface. An antibody specific for Dectin-1 coupled to ovalbumin has been demonstrated to induce not only $\mathrm{CD}^{+}$and $\mathrm{CD}^{+} \mathrm{T}$ cell responses, but also ovalbumin-specific antibody responses [215]. The same group has further investigated the expression of Dectin-1 in more detail and found it present on $\mathrm{CD} 11 \mathrm{c}^{+} \mathrm{MHC}-\mathrm{II}^{\mathrm{hi}} \mathrm{CD} 11 \mathrm{~b}^{+} \mathrm{CD} 8^{-} \mathrm{CD} 4^{-} \mathrm{DCs}$, which is, however, in contrast to previous reports showing expression also on $\mathrm{CD} 11 \mathrm{c}^{+} \mathrm{MHC}-\mathrm{II}^{\text {hi }} \mathrm{CD} 11 \mathrm{~b}^{+} \mathrm{CD} 8^{-} \mathrm{CD} 4^{+} \mathrm{DC}$ [259]. In contrast to murine studies, the delivery of the antigens hemagglutinin, flu-M1, or MART-1 to Dectin-1 on moDCs led to an activation of the targeted moDCs, the expansion of flu-M1 as well as MART-1-specific T cells, but also to a re-stimulation of memory Th17 cells. Besides CD4 ${ }^{+} \mathrm{T}$ cell responses, Dectin- 1 targeting was also promoting the differentiation of naïve $\mathrm{CD}^{+} \mathrm{T}$ cells into flu-M1-specific cytotoxic CD8 ${ }^{+} \mathrm{T}$ cells $[216,217]$.

Langerin (CD207 or Clec4K) is a key marker molecule of Langerhans' cells. Langerin is not only found on epidermal Langerhans' cells, but also on migratory Langerhans' cells and some dermal DC subsets, as well as on migratory DCs in lymph nodes [260]. As the receptor is especially present on those cell subsets, it attracted scientists to study the function of those cell subsets in the initiation of 
immune responses, as Langerin is involved in antigen recognition and uptake. The expression of Langerin is also connected to the presence of Birbeck granules [261]. The targeting of antigens via targeting antibodies to Langerin-expressing cells, including Langerhans' cells, but also CD103 ${ }^{+}$CD207 ${ }^{+}$ dermal DCs and CD8 ${ }^{+}$lymph node resident DCs, has been demonstrated to induce CD8 ${ }^{+}$and CD4 $4^{+} \mathrm{T}$ cell responses to ovalbumin and p24 of HIV after in vivo injection into naïve C57Bl/6 mice [178,184]. In contrast to this, Langerin targeting has been shown by Flacher, et al. to induce cross-tolerance in a B16F10-ova expressing tumor model, even when it is used in vivo with a strongly activating TLR ligand such as Imiquimod [218]. The same group also reported that ovalbumin targeting to Langerin was not inducing $\mathrm{CD}^{+}$or $\mathrm{CD}^{+} \mathrm{T}$ cell responses in contrast to DEC205 targeting to Langerhans' cells [202]. Recently, also Idoyaga, et al. demonstrated Langerhans' cells to induce tolerance without any co-stimulation to the MOG peptide in an EAE model [172], thereby suggesting a rather tolerogenic role after Langerin-specific antigen uptake.

Additionally, the direct targeting of antigens to pDCs using specifically expressed $C$ type lectins has been evaluated by taking advantage of antibodies specific for Siglec- $\mathrm{H}$, which is a highly endocytotically active receptor found on $\mathrm{pDCs}$ and $\mathrm{pDC}$ precursors [234]. Zhang, et al. also demonstrated Siglec-H targeting to be effective in the induction of naïve $\mathrm{CD}^{+} \mathrm{T}$ cell responses by combining a chemically coupled Siglec-H-ova conjugate and the TLR stimulus CpG [234]. By using a genetically coupled Siglec-H antibody without any co-stimulation Loschko, et al. demonstrated the potency of this method in inhibiting $\mathrm{T}$ cell dependent autoimmune reactions in an EAE model with MOG peptide as antigen [141].

Another promising and interesting receptor for antigen targeting is the $C$ type lectin-like receptor DC asialoglycoprotein receptor (DC-ASGPR, Clec10A, MGL, CD301) mainly expressed on immature DCs and granulocytes, but not on monocytes [262]. Antigen targeting of hemagglutinin with recombinant antibodies to DC-ASGPR on IFN $\alpha$-matured human moDCs did not only induce an antigen-specific $\mathrm{CD}^{+} \mathrm{T}$ cell proliferation, but also their predominant differentiation into IL-10 producers and to a lesser extend also IL-2 and IFN $\gamma$ [232]. This was true for the coupling of auto-antigens, such as prostate specific antigen (PSA) as well as foreign antigens, e.g., hemagglutinin (HA) [232].

\subsection{Other Receptors Used for Antigen Delivery to APCs}

The strategy of using antigen coupled antibodies against specifically expressed surface endocytic receptors is not limited to $C$ type lectin receptors. In fact, all receptors that fulfill important criteria, such as expression pattern, endocytic activity, routing to different compartments, as well as availability of suitable antibodies, can potentially be utilized. In the next section, we will provide some examples of other non $C$ type lectin and non lectin-like receptors, which have been utilized in a range of studies. Due to space constraints we could not discuss all possible candidates, but rather tried to discuss the most common and interesting examples. Also the targeting via Fc receptors using immune complexes will not be part of this review, as this strategy is not specific for a certain target receptor, but rather for a group of receptors dictating the outcome of this technique.

MHC-II is the molecule responsible for the presentation of antigenic self and foreign peptides to $\mathrm{CD}^{+} \mathrm{T}$ cells. It is constitutively expressed at high levels on all professional antigen presenting cells, such as DCs and B cells. Castro, et al. utilized different antibodies for various receptors, e.g., CD11c, MHC-II, and DEC205 to compare their efficiencies in antigen targeting. They chemically coupled the model antigen ovalbumin to these antibodies and measured the expansion of CD4 ${ }^{+}$and CD8 ${ }^{+}$ $\mathrm{T}$ cells, as well as the cytotoxic activity of the generated $\mathrm{CD}^{+} \mathrm{T}$ cells in vivo [227]. White, et al. also showed an ovalbumin-specific antibody response after targeting ovalbumin to MHC-II, though it was weaker than utilizing CD11c or CD18 as targeting receptor [208]. Dickgreber, et al. and also some other groups tested the usefulness of this receptor for antigen delivery to professional antigen presenting cells, even though it is not a receptor known to be highly endocytic. In contrast to using an antibody specific for MHC-II, they used the modified bacterial superantigen M1 (a modified version of the superantigen streptococcal mitogenic exotoxin Z-2 that binds to MHC class II molecules, but cannot 
directly stimulate T cells) and coupled it chemically to the model antigen ovalbumin. In addition to the cross-presentation of this antigen by all splenic DC subsets, they could demonstrate a delayed tumor growth of ovalbumin expressing melanoma cells in a therapeutic model [229].

CD11c, also known as ITGAX, is an alpha integrin highly expressed on murine cDCs, which can also be found to lower extends on other cells of the immune system, such as monocytes, macrophages, a subset of B cells, and pDCs. As CD11c has been regarded as a DC-specific receptor for a long time, scientists started to use it for antigen-delivery purposes. In 2000, Wang, et al. demonstrated fast antibody responses to polyclonal goat-anti-hamster antibodies complexed to a hamster-anti-CD11c antibody measured by goat-specific antibodies in the serum of intra-dermally vaccinated mice [263]. Later, the group of Glennie used a CD11c-specific antibody chemically coupled to ovalbumin. Targeting an anti CD11c antibody to CD11c positive cells led to the induction of strong CD4 ${ }^{+}$and $\mathrm{CD}^{+} \mathrm{T}$ cell responses, with the latter able to efficiently lyse ovalbumin expressing lymphoma cells (EL4) [227]. The final proof of effectiveness was provided by the group of Guo by taking advantage of a single chain $\mathrm{F}_{\mathrm{v}}$-specific for $\mathrm{CD} 11 \mathrm{c}$ and coupled to the breast cancer tumor antigen Her2/neu in combination with the co-stimulatory TLR ligand CPG. They could not only demonstrate the protective and therapeutic properties of this strategy by using Her2/neu expressing tumor cells, but also the delayed onset of tumor growth in a spontaneous mammary carcinoma mouse model [228].

Another molecule used for the delivery of antigens especially to pDCs is Bst-2 (CD317), also known as PDCA-1, tetherin, or HM1.24, which, in the steady-state, is restricted to this cell type within the murine immune system [264]. However, in dependency of the inflammatory stimulus, Bst-2 is downregulated on pDCs but upregulated on other cell types, such as classical DCs and plasma cells [265]. Sapoznikov, et al. used a Bst-2-specific F(ab')2-ova construct to deliver antigens to pDCs in vivo and showed an expansion of ovalbumin-specific transgenic CD8 ${ }^{+} \mathrm{T}$ cells, which was 1000 times less efficient than DEC205-ova targeting to CD8 ${ }^{+}$DCs. Interestingly, they could also show the induction of $\mathrm{CD}^{+}$transgenic $\mathrm{T}$ cell proliferation by lymph node pDCs, but not by splenic DCs [235]. Along with this, Loschko, et al. demonstrated-by targeting with Bst-2 specific whole antibodies mutated in their Fc region-that pDCs induced an efficient expansion of antigen-specific $\mathrm{CD}^{+}$and $\mathrm{CD} 8^{+} \mathrm{T}$ cells. Moreover, immune responses in naïve animals indicated a potent induction of specific antibody and $\mathrm{T}$ cell responses, with strong protective capacities demonstrated by challenging with a vaccinia-ova virus and in a s.c. B16F10-ova melanoma model [142].

The Scavenger receptor CD36 is an important receptor for antigen detection and uptake into a variety of phagocytically active cells, such as macrophages and DCs. Further, CD36 was also described to be expressed on a subset of B cells in the murine spleen. Interestingly, it is only present to a higher extend on murine $\mathrm{CD}^{+}$DCs of the spleen, but not on CD8 ${ }^{-}$DCs, monocytes, pDCs, or skin DCs [233]. In 2008, Tagliani, et al. demonstrated that CD36 might be a useful targeting receptor. This was demonstrated by delivery of ovalbumin antigen into murine CD ${ }^{+}$DCs by using a single chain $\mathrm{F}_{\mathrm{v}}$ fusion protein with a dimerizing $\gamma 1-\mathrm{CH} 3$ unit. The authors found that targeting of CD36 led to the induction of $\mathrm{CD}^{+}$and $\mathrm{CD}^{+}$antigen-specific $\mathrm{T}$ cells, but also to induction of cytotoxic $\mathrm{CD}^{+} \mathrm{T}$ cells as well as the differentiation of naïve $\mathrm{B}$ cells into ovalbumin-specific antibody producing plasma cells [233]. Recently, Pugholm, et al. demonstrated that targeting of CD36 led to the secretion of IL-4 and antibody responses without the administration of co-stimulatory agents in vitro and in vivo. They also reported these responses to be independent of the injection route (s.c./i.v./i.p) [266].

\section{Conclusions}

In the last decades, DCs have been recognized as professional antigen presenting cells indispensable for the control of the immune system. Many murine studies have utilized antibody mediated delivery of antigens to various kinds of endocytic receptors of DCs both in vitro and in vivo, and have demonstrated select DC subsets to be important for the induction of different immune responses. However, the actual influence of the respective receptor targeted on shaping the immune response still needs to be determined. One major pitfall of some of the antigen targeting studies 
is the chemical conjugation of antigens to the antibodies, which makes it difficult to calculate the precise antigen load per antibody. Another drawback for the correct interpretation of some of the results is the underestimated influence of the potential $\mathrm{Fc}_{\mathrm{c}}$ receptor mediated binding of the targeting antibodies. Moreover, expression and function of some of the described endocytic receptors in humans and other animal models, the identities of the antigen presenting cell populations as well as their abilities to regulate immune responses is not completely understood yet $[11,153,251,267]$. Solving the above-mentioned pitfalls will further accelerate the transfer of this technique of a specific induction of immune responses into the human system. This will help to develop strategies of both therapeutic as well as protective treatments of various kinds of human pathologies.

Acknowledgments: We would like to apologize to all those colleagues whose important contributions could not be cited directly due to space restrictions. This work was partly supported by the German Research Foundation (DU548/2-1, CRC643, CRC1181, RTG1962, RTG1660 to Diana Dudziak), the Bavarian Genome Research Network (BayGene) to Diana Dudziak, an intramural ELAN grant to Gordon F. Heidkamp (DE-14-10-17-1-Heidkamp), IZKF/ELAN grant to Christian H.K. Lehmann (IZKF-J54), and an IZKF grant to Diana Dudziak (IZKF-A65).

Author Contributions: Christian H.K. Lehmann and Diana Dudziak wrote the manuscript. Lukas Heger, Gordon F. Heidkamp, Anna Baranska, Jennifer J. Lühr, and Alana Hoffmann contributed to the writing and revision of the manuscript. Lukas Heger, Christian H.K. Lehmann, and Gordon F. Heidkamp prepared the table. Lukas Heger prepared the figure.

Conflicts of Interest: The authors declare no conflict of interest.

\section{References}

1. Sharpe, A.H.; Freeman, G.J. The B7-CD28 superfamily. Nat. Rev. Immunol. 2002, 2, 116-126. [CrossRef] [PubMed]

2. Steinman, R.M. Dendritic cells: Understanding immunogenicity. Eur. J. Immunol. 2007. [CrossRef] [PubMed]

3. Dudziak, D.; Kamphorst, A.O.; Heidkamp, G.F.; Buchholz, V.R.; Trumpfheller, C.; Yamazaki, S.; Cheong, C.; Liu, K.; Lee, H.W.; Park, C.G.; et al. Differential antigen processing by dendritic cell subsets in vivo. Science 2007, 315, 107-111. [CrossRef] [PubMed]

4. Steinman, R.M.; Hawiger, D.; Liu, K.; Bonifaz, L.; Bonnyay, D.; Mahnke, K.; Iyoda, T.; Ravetch, J.; Dhodapkar, M.; Inaba, K.; et al. Dendritic cell function in vivo during the steady state: A role in peripheral tolerance. Ann. NY Acad. Sci. 2003, 987, 15-25. [CrossRef] [PubMed]

5. Steinman, R.M.; Hawiger, D.; Nussenzweig, M.C. Tolerogenic dendritic cells. Ann. Rev. Immunol. 2003, 21, 685-711. [CrossRef] [PubMed]

6. Steinman, R.M.; Nussenzweig, M.C. Avoiding horror autotoxicus: The importance of dendritic cells in peripheral T cell tolerance. Proc. Nat. Acad. Sci. USA 2002, 99, 351-358. [CrossRef] [PubMed]

7. Yamazaki, S.; Dudziak, D.; Heidkamp, G.F.; Fiorese, C.; Bonito, A.J.; Inaba, K.; Nussenzweig, M.C.; Steinman, R.M. CD8 ${ }^{+}$CD205 ${ }^{+}$splenic dendritic cells are specialized to induce Foxp3 $3^{+}$regulatory T cells. J. Immunol. 2008, 181, 6923-6933. [CrossRef] [PubMed]

8. Hawiger, D.; Inaba, K.; Dorsett, Y.; Guo, M.; Mahnke, K.; Rivera, M.; Ravetch, J.V.; Steinman, R.M.; Nussenzweig, M.C. Dendritic cells induce peripheral T cell unresponsiveness under steady state conditions in vivo. J. Exp. Med. 2001, 194, 769-779. [CrossRef] [PubMed]

9. Hammad, H.; Lambrecht, B.N. Dendritic cells and airway epithelial cells at the interface between innate and adaptive immune responses. Allergy 2011, 66, 579-587. [CrossRef] [PubMed]

10. Joffre, O.; Nolte, M.A.; Sporri, R.; Reis e Sousa, C. Inflammatory signals in dendritic cell activation and the induction of adaptive immunity. Immunol. Rev. 2009, 227, 234-247. [CrossRef] [PubMed]

11. Merad, M.; Sathe, P.; Helft, J.; Miller, J.; Mortha, A. The dendritic cell lineage: Ontogeny and function of dendritic cells and their subsets in the steady state and the inflamed setting. Ann. Rev. Immunol. 2013, 31, 563-604. [CrossRef] [PubMed]

12. Banchereau, J.; Steinman, R.M. Dendritic cells and the control of immunity. Nature 1998, 392, $245-252$. [CrossRef] [PubMed]

13. Shortman, K.; Liu, Y.J. Mouse and human dendritic cell subtypes. Nat. Rev. Immunol. 2002, 2, $151-161$. [CrossRef] [PubMed]

14. Akira, S.; Uematsu, S.; Takeuchi, O. Pathogen recognition and innate immunity. Cell 2006, 124, $783-801$. [CrossRef] [PubMed] 
15. Bowie, A.; O'Neill, L.A. The interleukin-1 receptor/toll-like receptor superfamily: Signal generators for pro-inflammatory interleukins and microbial products. J. Leukoc. Biol. 2000, 67, 508-514. [PubMed]

16. Brencicova, E.; Diebold, S.S. Nucleic acids and endosomal pattern recognition: How to tell friend from foe? Front. Cell. Infect. Microbiol. 2013. [CrossRef] [PubMed]

17. Cambi, A.; Figdor, C.G. Dual function of C-type lectin-like receptors in the immune system. Curr. Opin. Cell Biol. 2003, 15, 539-546. [CrossRef] [PubMed]

18. Figdor, C.G.; van Kooyk, Y.; Adema, G.J. C-type lectin receptors on dendritic cells and langerhans cells. Nat. Rev. Immunol. 2002, 2, 77-84. [CrossRef] [PubMed]

19. Ottenhoff, T.H.; Bevan, M.J. Host-pathogen interactions. Curr. Opin. Immunol. 2004, 16, 439-442. [CrossRef] [PubMed]

20. Segura, E.; Villadangos, J.A. Antigen presentation by dendritic cells in vivo. Curr. Opin. Immunol. 2009, 21, 105-110. [CrossRef] [PubMed]

21. Swiecki, M.; Colonna, M. The multifaceted biology of plasmacytoid dendritic cells. Nat. Rev. Immunol. 2015, 15, 471-485. [CrossRef] [PubMed]

22. Takeuchi, O.; Akira, S. Pattern recognition receptors and inflammation. Cell 2010, 140, 805-820. [CrossRef] [PubMed]

23. Pufnock, J.S.; Cigal, M.; Rolczynski, L.S.; Andersen-Nissen, E.; Wolfl, M.; McElrath, M.J.; Greenberg, P.D. Priming $\mathrm{CD}^{+} \mathrm{T}$ cells with dendritic cells matured using TLR4 and TLR7/8 ligands together enhances generation of $\mathrm{CD}^{+} \mathrm{T}$ cells retaining CD28. Blood 2011, 117, 6542-6551. [CrossRef] [PubMed]

24. Shen, H.; Tesar, B.M.; Walker, W.E.; Goldstein, D.R. Dual signaling of MyD88 and trif is critical for maximal TLR4-induced dendritic cell maturation. J. Immunol. 2008, 181, 1849-1858. [CrossRef] [PubMed]

25. Delamarre, L.; Holcombe, H.; Mellman, I. Presentation of exogenous antigens on major histocompatibility complex (MHC) class I and MHC class II molecules is differentially regulated during dendritic cell maturation. J. Exp. Med. 2003, 198, 111-122. [CrossRef] [PubMed]

26. Kaufmann, S.H. The contribution of immunology to the rational design of novel antibacterial vaccines. Nat. Rev. Microbiol. 2007, 5, 491-504. [CrossRef] [PubMed]

27. Bowie, A.G.; Unterholzner, L. Viral evasion and subversion of pattern-recognition receptor signalling. Nat. Rev. Immunol. 2008, 8, 911-922. [CrossRef] [PubMed]

28. Varki, A.; Etzler, M.E.; Cummings, R.D.; Esko, J.D. Discovery and classification of glycan-binding proteins. In Essentials of Glycobiology, 2nd ed.; Varki, A., Cummings, R.D., Esko, J.D., Freeze, H.H., Stanley, P., Bertozzi, C.R., Hart, G.W., Etzler, M.E., Eds.; Cold Spring Harbor: New York, NY, USA, 2009.

29. Geijtenbeek, T.B.; Gringhuis, S.I. Signalling through C-type lectin receptors: Shaping immune responses. Nat. Rev. Immunol. 2009, 9, 465-479. [CrossRef] [PubMed]

30. Van Kooyk, Y.; Rabinovich, G.A. Protein-glycan interactions in the control of innate and adaptive immune responses. Nat. Immunol. 2008, 9, 593-601. [CrossRef] [PubMed]

31. Giraldi-Guimaraes, A.; de Freitas, H.T.; Coelho Bde, P.; Macedo-Ramos, H.; Mendez-Otero, R.; Cavalcante, L.A.; Baetas-da-Cruz, W. Bone marrow mononuclear cells and mannose receptor expression in focal cortical ischemia. Brain Res. 2012, 1452, 173-184. [CrossRef] [PubMed]

32. Hoque, R.; Malik, A.F.; Gorelick, F.; Mehal, W.Z. Sterile inflammatory response in acute pancreatitis. Pancreas 2012, 41, 353-357. [CrossRef] [PubMed]

33. Mathew, A.; Lindsley, T.A.; Sheridan, A.; Bhoiwala, D.L.; Hushmendy, S.F.; Yager, E.J.; Ruggiero, E.A.; Crawford, D.R. Degraded mitochondrial DNA is a newly identified subtype of the damage associated molecular pattern (DAMP) family and possible trigger of neurodegeneration. J. Alzheimers Dis. 2012, 30, 617-627. [PubMed]

34. Sancho, D.; Joffre, O.P.; Keller, A.M.; Rogers, N.C.; Martinez, D.; Hernanz-Falcon, P.; Rosewell, I.; Reis e Sousa, C. Identification of a dendritic cell receptor that couples sensing of necrosis to immunity. Nature 2009, 458, 899-903. [CrossRef] [PubMed]

35. Anton, L.C.; Yewdell, J.W. Translating drips: MHC class I immunosurveillance of pathogens and tumors. J. Leukoc. Biol. 2014, 95, 551-562. [CrossRef] [PubMed]

36. Lutz, M.B.; Schuler, G. Immature, semi-mature and fully mature dendritic cells: Which signals induce tolerance or immunity? Trends Immunol. 2002, 23, 445-449. [CrossRef]

37. Schwartz, R.H. Acquisition of immunologic self-tolerance. Cell 1989, 57, 1073-1081. [CrossRef] 
38. Copier, J.; Bodman-Smith, M.; Dalgleish, A. Current status and future applications of cellular therapies for cancer. Immunotherapy 2011, 3, 507-516. [CrossRef] [PubMed]

39. Keler, T.; He, L.; Ramakrishna, V.; Champion, B. Antibody-targeted vaccines. Oncogene 2007, 26, 3758-3767. [CrossRef] [PubMed]

40. Osada, T.; Nagaoka, K.; Takahara, M.; Yang, X.Y.; Liu, C.X.; Guo, H.; Roy Choudhury, K.; Hobeika, A.; Hartman, Z.; Morse, M.A.; et al. Precision cancer immunotherapy: Optimizing dendritic cell-based strategies to induce tumor antigen-specific $\mathrm{t}$-cell responses against individual patient tumors. J. Immunother. 2015, 38, 155-164. [CrossRef] [PubMed]

41. Palucka, K.; Banchereau, J. Cancer immunotherapy via dendritic cells. Nat. Rev. Cancer 2012, 12, $265-277$. [CrossRef] [PubMed]

42. Schuler, P.J.; Harasymczuk, M.; Visus, C.; Deleo, A.; Trivedi, S.; Lei, Y.; Argiris, A.; Gooding, W.; Butterfield, L.H.; Whiteside, T.L.; et al. Phase I dendritic cell p53 peptide vaccine for head and neck cancer. Clin. Cancer Res. 2014, 20, 2433-2444. [CrossRef] [PubMed]

43. Tacken, P.J.; Figdor, C.G. Targeted antigen delivery and activation of dendritic cells in vivo: Steps towards cost effective vaccines. Semin. Immunol. 2011, 23, 12-20. [CrossRef] [PubMed]

44. Steinman, R.M.; Banchereau, J. Taking dendritic cells into medicine. Nature 2007, 449, 419-426. [CrossRef] [PubMed]

45. Jonuleit, H.; Kuhn, U.; Muller, G.; Steinbrink, K.; Paragnik, L.; Schmitt, E.; Knop, J.; Enk, A.H. Pro-inflammatory cytokines and prostaglandins induce maturation of potent immunostimulatory dendritic cells under fetal calf serum-free conditions. Eur. J. Immunol. 1997, 27, 3135-3142. [CrossRef] [PubMed]

46. Romani, N.; Koide, S.; Crowley, M.; Witmer-Pack, M.; Livingstone, A.M.; Fathman, C.G.; Inaba, K.; Steinman, R.M. Presentation of exogenous protein antigens by dendritic cells to T cell clones. Intact protein is presented best by immature, epidermal langerhans cells. J. Exp. Med. 1989, 169, 1169-1178. [CrossRef] [PubMed]

47. Sallusto, F.; Cella, M.; Danieli, C.; Lanzavecchia, A. Dendritic cells use macropinocytosis and the mannose receptor to concentrate macromolecules in the major histocompatibility complex class II compartment: Downregulation by cytokines and bacterial products. J. Exp. Med. 1995, 182, 389-400. [CrossRef] [PubMed]

48. Sallusto, F.; Lanzavecchia, A. Efficient presentation of soluble antigen by cultured human dendritic cells is maintained by granulocyte/macrophage colony-stimulating factor plus interleukin 4 and downregulated by tumor necrosis factor alpha. J. Exp. Med. 1994, 179, 1109-1118. [CrossRef] [PubMed]

49. Schuler-Thurner, B.; Schultz, E.S.; Berger, T.G.; Weinlich, G.; Ebner, S.; Woerl, P.; Bender, A.; Feuerstein, B.; Fritsch, P.O.; Romani, N.; et al. Rapid induction of tumor-specific type $1 \mathrm{~T}$ helper cells in metastatic melanoma patients by vaccination with mature, cryopreserved, peptide-loaded monocyte-derived dendritic cells. J. Exp. Med. 2002, 195, 1279-1288. [CrossRef] [PubMed]

50. Guilliams, M.; Bruhns, P.; Saeys, Y.; Hammad, H.; Lambrecht, B.N. The function of fcgamma receptors in dendritic cells and macrophages. Nat. Rev. Immunol. 2014, 14, 94-108. [CrossRef] [PubMed]

51. de Vries, I.J.; Lesterhuis, W.J.; Scharenborg, N.M.; Engelen, L.P.; Ruiter, D.J.; Gerritsen, M.J.; Croockewit, S.; Britten, C.M.; Torensma, R.; Adema, G.J.; et al. Maturation of dendritic cells is a prerequisite for inducing immune responses in advanced melanoma patients. Clin. Cancer Res. 2003, 9, 5091-5100. [PubMed]

52. Dhodapkar, M.V.; Krasovsky, J.; Steinman, R.M.; Bhardwaj, N. Mature dendritic cells boost functionally superior CD8(+) t-cell in humans without foreign helper epitopes. J. Clin. Investig. 2000, 105, 9-14. [CrossRef] [PubMed]

53. Mahnke, K.; Schmitt, E.; Bonifaz, L.; Enk, A.H.; Jonuleit, H. Immature, but not inactive: The tolerogenic function of immature dendritic cells. Immunol. Cell Biol. 2002, 80, 477-483. [CrossRef] [PubMed]

54. Schuler, G. Dendritic cells in cancer immunotherapy. Eur. J. Immunol. 2010, 40, 2123-2130. [CrossRef] [PubMed]

55. Fong, L.; Brockstedt, D.; Benike, C.; Wu, L.; Engleman, E.G. Dendritic cells injected via different routes induce immunity in cancer patients. J. Immunol. 2001, 166, 4254-4259. [CrossRef] [PubMed]

56. Jonuleit, H.; Giesecke-Tuettenberg, A.; Tuting, T.; Thurner-Schuler, B.; Stuge, T.B.; Paragnik, L.; Kandemir, A.; Lee, P.P.; Schuler, G.; Knop, J.; et al. A comparison of two types of dendritic cell as adjuvants for the induction of melanoma-specific t-cell responses in humans following intranodal injection. Int. J. Cancer. 2001, 93, 243-251. [CrossRef] [PubMed]

57. Oshita, C.; Takikawa, M.; Kume, A.; Miyata, H.; Ashizawa, T.; Iizuka, A.; Kiyohara, Y.; Yoshikawa, S.; Tanosaki, R.; Yamazaki, N.; et al. Dendritic cell-based vaccination in metastatic melanoma patients: Phase ii clinical trial. Oncol. Rep. 2012, 28, 1131-1138. [PubMed] 
58. Tada, F.; Abe, M.; Hirooka, M.; Ikeda, Y.; Hiasa, Y.; Lee, Y.; Jung, N.C.; Lee, W.B.; Lee, H.S.; Bae, Y.S.; et al. Phase I/II study of immunotherapy using tumor antigen-pulsed dendritic cells in patients with hepatocellular carcinoma. Int. J. Oncol. 2012, 41, 1601-1609. [PubMed]

59. Ardon, H.; Van Gool, S.W.; Verschuere, T.; Maes, W.; Fieuws, S.; Sciot, R.; Wilms, G.; Demaerel, P.; Goffin, J.; Van Calenbergh, F.; et al. Integration of autologous dendritic cell-based immunotherapy in the standard of care treatment for patients with newly diagnosed glioblastoma: Results of the HGG-2006 phase I/II trial. Cancer Immunol. Immunother. 2012, 61, 2033-2044. [CrossRef] [PubMed]

60. Celluzzi, C.M.; Falo, L.D., Jr. Physical interaction between dendritic cells and tumor cells results in an immunogen that induces protective and therapeutic tumor rejection. J. Immunol. 1998, 160, 3081-3085. [PubMed]

61. Chang, A.E.; Redman, B.G.; Whitfield, J.R.; Nickoloff, B.J.; Braun, T.M.; Lee, P.P.; Geiger, J.D.; Mule, J.J. A phase I trial of tumor lysate-pulsed dendritic cells in the treatment of advanced cancer. Clin. Cancer Res. 2002, 8, 1021-1032. [PubMed]

62. El Ansary, M.; Mogawer, S.; Elhamid, S.A.; Alwakil, S.; Aboelkasem, F.; Sabaawy, H.E.; Abdelhalim, O. Immunotherapy by autologous dendritic cell vaccine in patients with advanced HCC. J. Cancer Res. Clin. Oncol. 2013, 139, 39-48. [CrossRef] [PubMed]

63. Gao, D.; Li, C.; Xie, X.; Zhao, P.; Wei, X.; Sun, W.; Liu, H.C.; Alexandrou, A.T.; Jones, J.; Zhao, R.; et al. Autologous tumor lysate-pulsed dendritic cell immunotherapy with cytokine-induced killer cells improves survival in gastric and colorectal cancer patients. PLoS ONE 2014, 9, e93886. [CrossRef] [PubMed]

64. Hunyadi, J.; Andras, C.; Szabo, I.; Szanto, J.; Szluha, K.; Sipka, S.; Kovacs, P.; Kiss, A.; Szegedi, G.; Altorjay, I.; et al. Autologous dendritic cell based adoptive immunotherapy of patients with colorectal cancer-a phase I-II study. Pathol. Oncol. Res. 2014, 20, 357-365. [CrossRef] [PubMed]

65. Matsushita, H.; Enomoto, Y.; Kume, H.; Nakagawa, T.; Fukuhara, H.; Suzuki, M.; Fujimura, T.; Homma, Y.; Kakimi, K. A pilot study of autologous tumor lysate-loaded dendritic cell vaccination combined with sunitinib for metastatic renal cell carcinoma. J. Immunother. Cancer 2014. [CrossRef] [PubMed]

66. Nouri-Shirazi, M.; Banchereau, J.; Bell, D.; Burkeholder, S.; Kraus, E.T.; Davoust, J.; Palucka, K.A. Dendritic cells capture killed tumor cells and present their antigens to elicit tumor-specific immune responses. J. Immunol. 2000, 165, 3797-3803. [CrossRef] [PubMed]

67. Aarntzen, E.H.; Schreibelt, G.; Bol, K.; Lesterhuis, W.J.; Croockewit, A.J.; de Wilt, J.H.; van Rossum, M.M.; Blokx, W.A.; Jacobs, J.F.; Duiveman-de Boer, T.; et al. Vaccination with mRNA-electroporated dendritic cells induces robust tumor antigen-specific $\mathrm{CD}^{+}$and $\mathrm{CD} 8^{+} \mathrm{T}$ cells responses in stage III and IV melanoma patients. Clin. Cancer Res. 2012, 18, 5460-5470. [CrossRef] [PubMed]

68. Dannull, J.; Haley, N.R.; Archer, G.; Nair, S.; Boczkowski, D.; Harper, M.; De Rosa, N.; Pickett, N.; Mosca, P.J.; Burchette, J.; et al. Melanoma immunotherapy using mature DCS expressing the constitutive proteasome. J. Clin. Investig. 2013, 123, 3135-3145. [CrossRef] [PubMed]

69. Heiser, A.; Maurice, M.A.; Yancey, D.R.; Wu, N.Z.; Dahm, P.; Pruitt, S.K.; Boczkowski, D.; Nair, S.K.; Ballo, M.S.; Gilboa, E.; et al. Induction of polyclonal prostate cancer-specific CTL using dendritic cells transfected with amplified tumor RNA. J. Immunol. 2001, 166, 2953-2960. [CrossRef] [PubMed]

70. Nair, S.K.; Morse, M.; Boczkowski, D.; Cumming, R.I.; Vasovic, L.; Gilboa, E.; Lyerly, H.K. Induction of tumor-specific cytotoxic T lymphocytes in cancer patients by autologous tumor RNA-transfected dendritic cells. Ann. Surg. 2002, 235, 540-549. [CrossRef] [PubMed]

71. Schaft, N.; Wellner, V.; Wohn, C.; Schuler, G.; Dorrie, J. CD8(+) T-cell priming and boosting: More antigen-presenting DC, or more antigen per DC? Cancer Immunol. Immunother. 2013, 62, 1769-1780. [CrossRef] [PubMed]

72. Schuurhuis, D.H.; Verdijk, P.; Schreibelt, G.; Aarntzen, E.H.; Scharenborg, N.; de Boer, A.; van de Rakt, M.W.; Kerkhoff, M.; Gerritsen, M.J.; Eijckeler, F.; et al. In situ expression of tumor antigens by messenger RNA-electroporated dendritic cells in lymph nodes of melanoma patients. Cancer Res. 2009, 69, 2927-2934. [CrossRef] [PubMed]

73. Van Craenenbroeck, A.H.; Smits, E.L.; Anguille, S.; Van de Velde, A.; Stein, B.; Braeckman, T.; Van Camp, K.; Nijs, G.; Ieven, M.; Goossens, H.; et al. Induction of cytomegalovirus-specific T cell responses in healthy volunteers and allogeneic stem cell recipients using vaccination with messenger RNA-transfected dendritic cells. Transplantation 2015, 99, 120-127. [CrossRef] [PubMed]

74. Bagley, K.C.; Lewis, G.K.; Fouts, T.R. Adjuvant activity of the catalytic a1 domain of cholera toxin for retroviral antigens delivered by genegun. Clin. Vaccine Immunol. 2011, 18, 922-930. [CrossRef] [PubMed] 
75. Condon, C.; Watkins, S.C.; Celluzzi, C.M.; Thompson, K.; Falo, L.D., Jr. DNA-based immunization by in vivo transfection of dendritic cells. Nat. Med. 1996, 2, 1122-1128. [CrossRef] [PubMed]

76. Harrison, R.A.; Richards, A.; Laing, G.D.; Theakston, R.D. Simultaneous genegun immunisation with plasmids encoding antigen and GM-CSF: Significant enhancement of murine antivenom IgG1 titres. Vaccine 2002, 20, 1702-1706. [CrossRef]

77. Whiteside, T.L.; Gambotto, A.; Albers, A.; Stanson, J.; Cohen, E.P. Human tumor-derived genomic DNA transduced into a recipient cell induces tumor-specific immune responses ex vivo. Proc. Nat. Acad. Sci. USA 2002, 99, 9415-9420. [CrossRef] [PubMed]

78. Vik-Mo, E.O.; Nyakas, M.; Mikkelsen, B.V.; Moe, M.C.; Due-Tonnesen, P.; Suso, E.M.; Saeboe-Larssen, S.; Sandberg, C.; Brinchmann, J.E.; Helseth, E.; et al. Therapeutic vaccination against autologous cancer stem cells with mRNA-transfected dendritic cells in patients with glioblastoma. Cancer Immunol. Immunother. 2013, 62, 1499-1509. [CrossRef] [PubMed]

79. Hammad, H.; Lambrecht, B.N. Dendritic cells and epithelial cells: Linking innate and adaptive immunity in asthma. Nat. Rev. Immunol. 2008, 8, 193-204. [CrossRef] [PubMed]

80. Kissick, H.T.; Sanda, M.G. The role of active vaccination in cancer immunotherapy: Lessons from clinical trials. Curr. Opin. Immunol. 2015, 35, 15-22. [CrossRef] [PubMed]

81. Nestle, F.O.; Banchereau, J.; Hart, D. Dendritic cells: On the move from bench to bedside. Nat. Med. 2001, 7, 761-765. [CrossRef] [PubMed]

82. Mayanagi, S.; Kitago, M.; Sakurai, T.; Matsuda, T.; Fujita, T.; Higuchi, H.; Taguchi, J.; Takeuchi, H.; Itano, O.; Aiura, K.; et al. Phase I pilot study of wilms tumor gene 1 peptide-pulsed dendritic cell vaccination combined with gemcitabine in pancreatic cancer. Cancer Sci. 2015, 106, 397-406. [CrossRef] [PubMed]

83. Mitchell, D.A.; Batich, K.A.; Gunn, M.D.; Huang, M.N.; Sanchez-Perez, L.; Nair, S.K.; Congdon, K.L.; Reap, E.A.; Archer, G.E.; Desjardins, A.; et al. Tetanus toxoid and CCL3 improve dendritic cell vaccines in mice and glioblastoma patients. Nature 2015, 519, 366-369. [CrossRef] [PubMed]

84. Chodon, T.; Comin-Anduix, B.; Chmielowski, B.; Koya, R.C.; Wu, Z.; Auerbach, M.; Ng, C.; Avramis, E.; Seja, E.; Villanueva, A.; et al. Adoptive transfer of MART-1 T-cell receptor transgenic lymphocytes and dendritic cell vaccination in patients with metastatic melanoma. Clin. Cancer Res. 2014, 20, 2457-2465. [CrossRef] [PubMed]

85. Dhodapkar, M.V.; Sznol, M.; Zhao, B.; Wang, D.; Carvajal, R.D.; Keohan, M.L.; Chuang, E.; Sanborn, R.E.; Lutzky, J.; Powderly, J.; et al. Induction of antigen-specific immunity with a vaccine targeting NY-ESO-1 to the dendritic cell receptor DEC-205. Sci. Transl. Med. 2014. [CrossRef] [PubMed]

86. Nestle, F.O.; Alijagic, S.; Gilliet, M.; Sun, Y.; Grabbe, S.; Dummer, R.; Burg, G.; Schadendorf, D. Vaccination of melanoma patients with peptide-Or tumor lysate-Oulsed dendritic cells. Nat. Med. 1998, 4, 328-332. [CrossRef] [PubMed]

87. Poschke, I.; Lovgren, T.; Adamson, L.; Nystrom, M.; Andersson, E.; Hansson, J.; Tell, R.; Masucci, G.V.; Kiessling, R. A phase I clinical trial combining dendritic cell vaccination with adoptive $\mathrm{T}$ cell transfer in patients with stage IV melanoma. Cancer Immunol. Immunother. 2014, 63, 1061-1071. [CrossRef] [PubMed]

88. Thurner, B.; Haendle, I.; Roder, C.; Dieckmann, D.; Keikavoussi, P.; Jonuleit, H.; Bender, A.; Maczek, C.; Schreiner, D.; von den Driesch, P.; et al. Vaccination with MAGE-3A1 peptide-pulsed mature, monocyte-derived dendritic cells expands specific cytotoxic $T$ cells and induces regression of some metastases in advanced stage IV melanoma. J. Exp. Med. 1999, 190, 1669-1678. [CrossRef] [PubMed]

89. Aarntzen, E.H.; De Vries, I.J.; Lesterhuis, W.J.; Schuurhuis, D.; Jacobs, J.F.; Bol, K.; Schreibelt, G.; Mus, R.; De Wilt, J.H.; Haanen, J.B.; et al. Targeting CD4(+) T-helper cells improves the induction of antitumor responses in dendritic cell-based vaccination. Cancer Res. 2013, 73, 19-29. [CrossRef] [PubMed]

90. Engell-Noerregaard, L.; Hansen, T.H.; Andersen, M.H.; Thor Straten, P.; Svane, I.M. Review of clinical studies on dendritic cell-based vaccination of patients with malignant melanoma: Assessment of correlation between clinical response and vaccine parameters. Cancer Immunol. Immunother. 2009, 58, 1-14. [CrossRef] [PubMed]

91. Hobo, W.; Strobbe, L.; Maas, F.; Fredrix, H.; Greupink-Draaisma, A.; Esendam, B.; de Witte, T.; Preijers, F.; Levenga, H.; van Rees, B.; et al. Immunogenicity of dendritic cells pulsed with MAGE3, survivin and B-cell maturation antigen mRNA for vaccination of multiple myeloma patients. Cancer Immunol. Immunother. 2013, 62, 1381-1392. [CrossRef] [PubMed]

92. Murthy, V.; Moiyadi, A.; Sawant, R.; Sarin, R. Clinical considerations in developing dendritic cell vaccine based immunotherapy protocols in cancer. Curr. Mol. Med. 2009, 9, 725-731. [CrossRef] [PubMed] 
93. Butterfield, L.H. Cancer vaccines. BMJ 2015. [CrossRef] [PubMed]

94. Mahoney, K.M.; Rennert, P.D.; Freeman, G.J. Combination cancer immunotherapy and new immunomodulatory targets. Nat. Rev. Drug Discov. 2015, 14, 561-584. [CrossRef] [PubMed]

95. Pizzurro, G.A.; Barrio, M.M. Dendritic cell-based vaccine efficacy: Aiming for hot spots. Front. Immunol. 2015. [CrossRef] [PubMed]

96. Melero, I.; Gaudernack, G.; Gerritsen, W.; Huber, C.; Parmiani, G.; Scholl, S.; Thatcher, N.; Wagstaff, J.; Zielinski, C.; Faulkner, I.; et al. Therapeutic vaccines for cancer: An overview of clinical trials. Nat. Rev. Clin. Oncol. 2014, 11, 509-524. [CrossRef] [PubMed]

97. Hodi, F.S.; O’Day, S.J.; McDermott, D.F.; Weber, R.W.; Sosman, J.A.; Haanen, J.B.; Gonzalez, R.; Robert, C.; Schadendorf, D.; Hassel, J.C.; et al. Improved survival with ipilimumab in patients with metastatic melanoma. N. Engl. J. Med. 2010, 363, 711-723. [CrossRef] [PubMed]

98. Lawson, D.H.; Lee, S.; Zhao, F.; Tarhini, A.A.; Margolin, K.A.; Ernstoff, M.S.; Atkins, M.B.; Cohen, G.I.; Whiteside, T.L.; Butterfield, L.H.; et al. Randomized, placebo-controlled, phase III trial of yeast-derived granulocyte-macrophage colony-stimulating factor (GM-CSF) versus peptide vaccination versus GM-CSF plus peptide vaccination versus placebo in patients with no evidence of disease after complete surgical resection of locally advanced and/or stage IV melanoma: A trial of the eastern cooperative oncology group-american college of radiology imaging network cancer research group (e4697). J. Clin. Oncol. 2015, 33, 4066-4076. [PubMed]

99. Noguchi, M.; Moriya, F.; Suekane, S.; Matsuoka, K.; Arai, G.; Matsueda, S.; Sasada, T.; Yamada, A.; Itoh, K. Phase II study of personalized peptide vaccination for castration-resistant prostate cancer patients who failed in docetaxel-based chemotherapy. Prostate 2012, 72, 834-845. [CrossRef] [PubMed]

100. Pol, J.; Bloy, N.; Buque, A.; Eggermont, A.; Cremer, I.; Sautes-Fridman, C.; Galon, J.; Tartour, E.; Zitvogel, L.; Kroemer, G.; et al. Trial watch: Peptide-based anticancer vaccines. Oncoimmunology 2015. [CrossRef] [PubMed]

101. Schuster, J.; Lai, R.K.; Recht, L.D.; Reardon, D.A.; Paleologos, N.A.; Groves, M.D.; Mrugala, M.M.; Jensen, R.; Baehring, J.M.; Sloan, A.; et al. A phase ii, multicenter trial of rindopepimut (CDX-110) in newly diagnosed glioblastoma: The act III study. Neuro-Oncology 2015, 17, 854-861. [CrossRef] [PubMed]

102. Schwartzentruber, D.J.; Lawson, D.H.; Richards, J.M.; Conry, R.M.; Miller, D.M.; Treisman, J.; Gailani, F.; Riley, L.; Conlon, K.; Pockaj, B.; et al. Gp100 peptide vaccine and interleukin-2 in patients with advanced melanoma. N. Engl. J. Med. 2011, 364, 2119-2127. [CrossRef] [PubMed]

103. McNeel, D.G.; Dunphy, E.J.; Davies, J.G.; Frye, T.P.; Johnson, L.E.; Staab, M.J.; Horvath, D.L.; Straus, J.; Alberti, D.; Marnocha, R.; et al. Safety and immunological efficacy of a DNA vaccine encoding prostatic acid phosphatase in patients with stage d0 prostate cancer. J. Clin. Oncol. 2009, 27, 4047-4054. [CrossRef] [PubMed]

104. Pavlenko, M.; Roos, A.K.; Lundqvist, A.; Palmborg, A.; Miller, A.M.; Ozenci, V.; Bergman, B.; Egevad, L.; Hellstrom, M.; Kiessling, R.; et al. A phase I trial of DNA vaccination with a plasmid expressing prostate-specific antigen in patients with hormone-refractory prostate cancer. Br. J. Cancer 2004, 91, 688-694. [CrossRef] [PubMed]

105. Fehres, C.M.; Kalay, H.; Bruijns, S.C.; Musaafir, S.A.; Ambrosini, M.; van Bloois, L.; van Vliet, S.J.; Storm, G.; Garcia-Vallejo, J.J.; van Kooyk, Y. Cross-presentation through langerin and DC-SIGN targeting requires different formulations of glycan-modified antigens. J. Control. Release 2015, 203, 67-76. [CrossRef] [PubMed]

106. Mansourian, M.; Badiee, A.; Jalali, S.A.; Shariat, S.; Yazdani, M.; Amin, M.; Jaafari, M.R. Effective induction of anti-tumor immunity using p5 HER-2/neu derived peptide encapsulated in fusogenic DOTAP cationic liposomes co-administrated with CpG-ODN. Immunol. Lett. 2014, 162, 87-93. [CrossRef] [PubMed]

107. Varypataki, E.M.; van der Maaden, K.; Bouwstra, J.; Ossendorp, F.; Jiskoot, W. Cationic liposomes loaded with a synthetic long peptide and poly(i:C): A defined adjuvanted vaccine for induction of antigen-specific $\mathrm{T}$ cell cytotoxicity. AAPS J. 2015, 17, 216-226. [CrossRef] [PubMed]

108. Wu, Y.L.; Park, K.; Soo, R.A.; Sun, Y.; Tyroller, K.; Wages, D.; Ely, G.; Yang, J.C.; Mok, T. Inspire: A phase III study of the BLP25 liposome vaccine (1-BLP25) in asian patients with unresectable stage III non-small cell lung cancer. BMC Cancer 2011. [CrossRef] [PubMed]

109. Berd, D. M-vax: An autologous, hapten-modified vaccine for human cancer. Expert Rev. Vaccines 2004, 3, 521-527. [CrossRef] [PubMed] 
110. Hersey, P.; Coates, A.S.; McCarthy, W.H.; Thompson, J.F.; Sillar, R.W.; McLeod, R.; Gill, P.G.; Coventry, B.J.; McMullen, A.; Dillon, H.; et al. Adjuvant immunotherapy of patients with high-risk melanoma using vaccinia viral lysates of melanoma: Results of a randomized trial. J. Clin. Oncol. 2002, 20, 4181-4190. [CrossRef] [PubMed]

111. Sondak, V.K.; Liu, P.Y.; Tuthill, R.J.; Kempf, R.A.; Unger, J.M.; Sosman, J.A.; Thompson, J.A.; Weiss, G.R.; Redman, B.G.; Jakowatz, J.G.; et al. Adjuvant immunotherapy of resected, intermediate-thickness, node-negative melanoma with an allogeneic tumor vaccine: Overall results of a randomized trial of the southwest oncology group. J. Clin. Oncol. 2002, 20, 2058-2066. [CrossRef] [PubMed]

112. Bijker, M.S.; Melief, C.J.; Offringa, R.; van der Burg, S.H. Design and development of synthetic peptide vaccines: Past, present and future. Expert Rev. Vaccines 2007, 6, 591-603. [CrossRef] [PubMed]

113. Vremec, D.; O’Keeffe, M.; Wilson, A.; Ferrero, I.; Koch, U.; Radtke, F.; Scott, B.; Hertzog, P.; Villadangos, J.; Shortman, K. Factors determining the spontaneous activation of splenic dendritic cells in culture. Innate Immun. 2011, 17, 338-352. [CrossRef] [PubMed]

114. Kamphorst, A.O.; Guermonprez, P.; Dudziak, D.; Nussenzweig, M.C. Route of antigen uptake differentially impacts presentation by dendritic cells and activated monocytes. J. Immunol. 2010, 185, 3426-3435. [CrossRef] [PubMed]

115. Joshi, M.D.; Unger, W.J.; Storm, G.; van Kooyk, Y.; Mastrobattista, E. Targeting tumor antigens to dendritic cells using particulate carriers. J. Control. Release 2012, 161, 25-37. [CrossRef] [PubMed]

116. Paulis, L.E.; Mandal, S.; Kreutz, M.; Figdor, C.G. Dendritic cell-based nanovaccines for cancer immunotherapy. Curr. Opin. Immunol. 2013, 25, 389-395. [CrossRef] [PubMed]

117. Reddy, S.T.; Swartz, M.A.; Hubbell, J.A. Targeting dendritic cells with biomaterials: Developing the next generation of vaccines. Trends Immunol. 2006, 27, 573-579. [CrossRef] [PubMed]

118. Ducancel, F.; Muller, B.H. Molecular engineering of antibodies for therapeutic and diagnostic purposes. MAbs 2012, 4, 445-457. [CrossRef] [PubMed]

119. Feige, M.J.; Buchner, J. Principles and engineering of antibody folding and assembly. Biochim. Biophys. Acta 2014, 1844, 2024-2031. [CrossRef] [PubMed]

120. Lazar, G.A.; Dang, W.; Karki, S.; Vafa, O.; Peng, J.S.; Hyun, L.; Chan, C.; Chung, H.S.; Eivazi, A.; Yoder, S.C.; et al. Engineered antibody fc variants with enhanced effector function. Proc. Nat. Acad. Sci. USA 2006, 103, 4005-4010. [CrossRef] [PubMed]

121. Li, F.; Ravetch, J.V. Inhibitory fcgamma receptor engagement drives adjuvant and anti-tumor activities of agonistic CD40 antibodies. Science 2011, 333, 1030-1034. [CrossRef] [PubMed]

122. Lux, A.; Nimmerjahn, F. Impact of differential glycosylation on IgG activity. Adv. Exp. Med. Biol. 2011, 780, 113-124. [PubMed]

123. Nimmerjahn, F.; Ravetch, J.V. Translating basic mechanisms of IgG effector activity into next generation cancer therapies. Cancer Immun. 2012, 12, 13. [PubMed]

124. Roopenian, D.C.; Akilesh, S. Fcrn: The neonatal fc receptor comes of age. Nat. Rev. Immunol. 2007, 7, 715-725. [CrossRef] [PubMed]

125. Ward, E.S.; Devanaboyina, S.C.; Ober, R.J. Targeting fcrn for the modulation of antibody dynamics. Mol. Immunol. 2015, 67, 131-141. [CrossRef] [PubMed]

126. Dong, H.; Stanek, O.; Salvador, F.R.; Langer, U.; Morillon, E.; Ung, C.; Sebo, P.; Leclerc, C.; Majlessi, L. Induction of protective immunity against mycobacterium tuberculosis by delivery of esx antigens into airway dendritic cells. Mucosal Immunol. 2013, 6, 522-534. [CrossRef] [PubMed]

127. Helft, J.; Ginhoux, F.; Bogunovic, M.; Merad, M. Origin and functional heterogeneity of non-lymphoid tissue dendritic cells in mice. Immunol. Rev. 2010, 234, 55-75. [CrossRef] [PubMed]

128. Hadeiba, H.; Sato, T.; Habtezion, A.; Oderup, C.; Pan, J.; Butcher, E.C. CCR9 expression defines tolerogenic plasmacytoid dendritic cells able to suppress acute graft-versus-host disease. Nat. Immunol. 2008, 9, 1253-1260. [CrossRef] [PubMed]

129. Wendland, M.; Czeloth, N.; Mach, N.; Malissen, B.; Kremmer, E.; Pabst, O.; Forster, R. CCR9 is a homing receptor for plasmacytoid dendritic cells to the small intestine. Proc. Nat. Acad. Sci. USA 2007, 104, 6347-6352. [CrossRef] [PubMed]

130. Ardavin, C. Origin, precursors and differentiation of mouse dendritic cells. Nat. Rev. Immunol. 2003, 3, 582-590. [CrossRef] [PubMed] 
131. Cella, M.; Jarrossay, D.; Facchetti, F.; Alebardi, O.; Nakajima, H.; Lanzavecchia, A.; Colonna, M. Plasmacytoid monocytes migrate to inflamed lymph nodes and produce large amounts of type I interferon. Nat. Med. 1999, 5, 919-923. [PubMed]

132. Gilliet, M.; Cao, W.; Liu, Y.J. Plasmacytoid dendritic cells: Sensing nucleic acids in viral infection and autoimmune diseases. Nat. Rev. Immunol. 2008, 8, 594-606. [CrossRef] [PubMed]

133. Gregorio, J.; Meller, S.; Conrad, C.; Di Nardo, A.; Homey, B.; Lauerma, A.; Arai, N.; Gallo, R.L.; Digiovanni, J.; Gilliet, M. Plasmacytoid dendritic cells sense skin injury and promote wound healing through type I interferons. J. Exp. Med. 2010, 207, 2921-2930. [CrossRef] [PubMed]

134. Rajagopal, D.; Paturel, C.; Morel, Y.; Uematsu, S.; Akira, S.; Diebold, S.S. Plasmacytoid dendritic cell-derived type I interferon is crucial for the adjuvant activity of toll-like receptor 7 agonists. Blood 2010, 115, 1949-1957. [CrossRef] [PubMed]

135. Segura, E.; Wong, J.; Villadangos, J.A. Cutting edge: $B 220^{+} \mathrm{CCR}{ }^{-}$dendritic cells are not plasmacytoid dendritic cells but are precursors of conventional dendritic cells. J. Immunol. 2009, 183, 1514-1517. [CrossRef] [PubMed]

136. Siegal, F.P.; Kadowaki, N.; Shodell, M.; Fitzgerald-Bocarsly, P.A.; Shah, K.; Ho, S.; Antonenko, S.; Liu, Y.J. The nature of the principal type 1 interferon-producing cells in human blood. Science 1999, 284, 1835-1837. [CrossRef] [PubMed]

137. Chappell, C.P.; Giltiay, N.V.; Draves, K.E.; Chen, C.; Hayden-Ledbetter, M.S.; Shlomchik, M.J.; Kaplan, D.H.; Clark, E.A. Targeting antigens through blood dendritic cell antigen 2 on plasmacytoid dendritic cells promotes immunologic tolerance. J. Immunol. 2014, 192, 5789-5801. [CrossRef] [PubMed]

138. Di Pucchio, T.; Chatterjee, B.; Smed-Sorensen, A.; Clayton, S.; Palazzo, A.; Montes, M.; Xue, Y.; Mellman, I.; Banchereau, J.; Connolly, J.E. Direct proteasome-independent cross-presentation of viral antigen by plasmacytoid dendritic cells on major histocompatibility complex class I. Nat. Immunol. 2008, 9, 551-557. [CrossRef] [PubMed]

139. Flores, M.; Desai, D.D.; Downie, M.; Liang, B.; Reilly, M.P.; McKenzie, S.E.; Clynes, R. Dominant expression of the inhibitory fcgammariib prevents antigen presentation by murine plasmacytoid dendritic cells. J. Immunol. 2009, 183, 7129-7139. [CrossRef] [PubMed]

140. Hoeffel, G.; Ripoche, A.C.; Matheoud, D.; Nascimbeni, M.; Escriou, N.; Lebon, P.; Heshmati, F.; Guillet, J.G.; Gannage, M.; Caillat-Zucman, S.; et al. Antigen crosspresentation by human plasmacytoid dendritic cells. Immunity 2007, 27, 481-492. [CrossRef] [PubMed]

141. Loschko, J.; Heink, S.; Hackl, D.; Dudziak, D.; Reindl, W.; Korn, T.; Krug, A.B. Antigen targeting to plasmacytoid dendritic cells via Siglec-H inhibits Th cell-dependent autoimmunity. J. Immunol. 2011, 187, 6346-6356. [CrossRef] [PubMed]

142. Loschko, J.; Schlitzer, A.; Dudziak, D.; Drexler, I.; Sandholzer, N.; Bourquin, C.; Reindl, W.; Krug, A.B. Antigen delivery to plasmacytoid dendritic cells via BST2 induces protective T cell-mediated immunity. J. Immunol. 2011, 186, 6718-6725. [CrossRef] [PubMed]

143. Meyer-Wentrup, F.; Benitez-Ribas, D.; Tacken, P.J.; Punt, C.J.; Figdor, C.G.; de Vries, I.J.; Adema, G.J. Targeting DCIR on human plasmacytoid dendritic cells results in antigen presentation and inhibits IFN-alpha production. Blood 2008, 111, 4245-4253. [CrossRef] [PubMed]

144. Mouries, J.; Moron, G.; Schlecht, G.; Escriou, N.; Dadaglio, G.; Leclerc, C. Plasmacytoid dendritic cells efficiently cross-prime naive T cells in vivo after TLR activation. Blood 2008, 112, 3713-3722. [CrossRef] [PubMed]

145. Reizis, B.; Bunin, A.; Ghosh, H.S.; Lewis, K.L.; Sisirak, V. Plasmacytoid dendritic cells: Recent progress and open questions. Ann. Rev. Immunol. 2011, 29, 163-183. [CrossRef] [PubMed]

146. Villadangos, J.A.; Schnorrer, P. Intrinsic and cooperative antigen-presenting functions of dendritic-cell subsets in vivo. Nat. Rev. Immunol. 2007, 7, 543-555. [CrossRef] [PubMed]

147. Gurka, S.; Hartung, E.; Becker, M.; Kroczek, R.A. Mouse conventional dendritic cells can be universally classified based on the mutually exclusive expression of XCR1 and sirpalpha. Front. Immunol. 2015. [CrossRef] [PubMed]

148. Miller, J.C.; Brown, B.D.; Shay, T.; Gautier, E.L.; Jojic, V.; Cohain, A.; Pandey, G.; Leboeuf, M.; Elpek, K.G.; Helft, J.; et al. Deciphering the transcriptional network of the dendritic cell lineage. Nat. Immunol. 2012, 13, 888-899. [CrossRef] [PubMed]

149. Malissen, B.; Tamoutounour, S.; Henri, S. The origins and functions of dendritic cells and macrophages in the skin. Nat. Rev. Immunol. 2014, 14, 417-428. [CrossRef] [PubMed] 
150. Langlet, C.; Tamoutounour, S.; Henri, S.; Luche, H.; Ardouin, L.; Gregoire, C.; Malissen, B.; Guilliams, M. CD64 expression distinguishes monocyte-derived and conventional dendritic cells and reveals their distinct role during intramuscular immunization. J. Immunol. 2012, 188, 1751-1760. [CrossRef] [PubMed]

151. Durand, M.; Segura, E. The known unknowns of the human dendritic cell network. Front. Immunol. 2015. [CrossRef] [PubMed]

152. Guilliams, M.; Ginhoux, F.; Jakubzick, C.; Naik, S.H.; Onai, N.; Schraml, B.U.; Segura, E.; Tussiwand, R.; Yona, S. Dendritic cells, monocytes and macrophages: A unified nomenclature based on ontogeny. Nat. Rev. Immunol. 2014, 14, 571-578. [CrossRef] [PubMed]

153. Heidkamp, G.F.; Lehmann, C.H.K.; Heger, L.; Baransk, A.; Hoffmann, A.; Lühr, J.; Dudziak, D. Functional specialization of dendritic cell subsets. In Encyclopedia of Cell Biology, 1st ed.; Academic Press: Waltham, UK, 2016; pp. 588-604.

154. Palucka, K.; Banchereau, J. Dendritic-cell-based therapeutic cancer vaccines. Immunity 2013, 39, 38-48. [CrossRef] [PubMed]

155. Reynolds, G.; Haniffa, M. Human and mouse mononuclear phagocyte networks: A tale of two species? Front. Immunol. 2015. [CrossRef] [PubMed]

156. Vu Manh, T.P.; Bertho, N.; Hosmalin, A.; Schwartz-Cornil, I.; Dalod, M. Investigating evolutionary conservation of dendritic cell subset identity and functions. Front. Immunol. 2015. [CrossRef] [PubMed]

157. Bonifaz, L.C.; Bonnyay, D.P.; Charalambous, A.; Darguste, D.I.; Fujii, S.; Soares, H.; Brimnes, M.K.; Moltedo, B.; Moran, T.M.; Steinman, R.M. In vivo targeting of antigens to maturing dendritic cells via the DEC-205 receptor improves T cell vaccination. J. Exp. Med. 2004, 199, 815-824. [CrossRef] [PubMed]

158. Lindquist, R.L.; Shakhar, G.; Dudziak, D.; Wardemann, H.; Eisenreich, T.; Dustin, M.L.; Nussenzweig, M.C. Visualizing dendritic cell networks in vivo. Nat. Immunol. 2004, 5, 1243-1250. [CrossRef] [PubMed]

159. Shakhar, G.; Lindquist, R.L.; Skokos, D.; Dudziak, D.; Huang, J.H.; Nussenzweig, M.C.; Dustin, M.L. Stable T cell-dendritic cell interactions precede the development of both tolerance and immunity in vivo. Nat. Immunol. 2005, 6, 707-714. [CrossRef] [PubMed]

160. Soares, H.; Waechter, H.; Glaichenhaus, N.; Mougneau, E.; Yagita, H.; Mizenina, O.; Dudziak, D.; Nussenzweig, M.C.; Steinman, R.M. A subset of dendritic cells induces CD4 ${ }^{+}$T cells to produce IFN-gamma by an IL-12-independent but CD70-dependent mechanism in vivo. J. Exp. Med. 2007, 204, 1095-1106. [CrossRef] [PubMed]

161. Jiang, W.; Swiggard, W.J.; Heufler, C.; Peng, M.; Mirza, A.; Steinman, R.M.; Nussenzweig, M.C. The receptor DEC-205 expressed by dendritic cells and thymic epithelial cells is involved in antigen processing. Nature 1995, 375, 151-155. [CrossRef] [PubMed]

162. Inaba, K.; Swiggard, W.J.; Inaba, M.; Meltzer, J.; Mirza, A.; Sasagawa, T.; Nussenzweig, M.C.; Steinman, R.M. Tissue distribution of the DEC-205 protein that is detected by the monoclonal antibody NLDC-145. I. Expression on dendritic cells and other subsets of mouse leukocytes. Cell. Immunol. 1995, 163, 148-156. [CrossRef] [PubMed]

163. Kraal, G.; Breel, M.; Janse, M.; Bruin, G. Langerhans' cells, veiled cells, and interdigitating cells in the mouse recognized by a monoclonal antibody. J. Exp. Med. 1986, 163, 981-997. [CrossRef] [PubMed]

164. Witmer-Pack, M.D.; Swiggard, W.J.; Mirza, A.; Inaba, K.; Steinman, R.M. Tissue distribution of the DEC-205 protein that is detected by the monoclonal antibody NLDC-145. II. Expression in situ in lymphoid and nonlymphoid tissues. Cell. Immunol. 1995, 163, 157-162. [CrossRef] [PubMed]

165. Mahnke, K.; Qian, Y.; Knop, J.; Enk, A.H. Induction of $\mathrm{CD} 4^{+} / \mathrm{CD} 25^{+}$regulatory $\mathrm{T}$ cells by targeting of antigens to immature dendritic cells. Blood 2003, 101, 4862-4869. [CrossRef] [PubMed]

166. Iyoda, T.; Shimoyama, S.; Liu, K.; Omatsu, Y.; Akiyama, Y.; Maeda, Y.; Takahara, K.; Steinman, R.M.; Inaba, K. The CD8 ${ }^{+}$dendritic cell subset selectively endocytoses dying cells in culture and in vivo. J. Exp. Med. 2002, 195, 1289-1302. [CrossRef] [PubMed]

167. Lahoud, M.H.; Ahmet, F.; Zhang, J.G.; Meuter, S.; Policheni, A.N.; Kitsoulis, S.; Lee, C.N.; O’Keeffe, M.; Sullivan, L.C.; Brooks, A.G.; et al. DEC-205 is a cell surface receptor for CPG oligonucleotides. Proc. Nat. Acad. Sci. USA 2012, 109, 16270-16275. [CrossRef] [PubMed]

168. Shrimpton, R.E.; Butler, M.; Morel, A.S.; Eren, E.; Hue, S.S.; Ritter, M.A. CD205 (DEC-205): A recognition receptor for apoptotic and necrotic self. Mol. Immunol. 2009, 46, 1229-1239. [CrossRef] [PubMed] 
169. Zhang, S.S.; Park, C.G.; Zhang, P.; Bartra, S.S.; Plano, G.V.; Klena, J.D.; Skurnik, M.; Hinnebusch, B.J.; Chen, T. Plasminogen activator Pla of Yersinia pestis utilizes murine DEC-205 (CD205) as a receptor to promote dissemination. J. Biol. Chem. 2008, 283, 31511-31521. [CrossRef] [PubMed]

170. Heidkamp, G.F.; Neubert, K.; Haertel, E.; Nimmerjahn, F.; Nussenzweig, M.C.; Dudziak, D. Efficient generation of a monoclonal antibody against the human C-type lectin receptor DCIR by targeting murine dendritic cells. Immunol. Lett. 2010, 132, 69-78. [CrossRef] [PubMed]

171. Henriques, H.R.; Rampazo, E.V.; Goncalves, A.J.; Vicentin, E.C.; Amorim, J.H.; Panatieri, R.H.; Amorim, K.N.; Yamamoto, M.M.; Ferreira, L.C.; Alves, A.M.; et al. Targeting the non-structural protein 1 from dengue virus to a dendritic cell population confers protective immunity to lethal virus challenge. PLoS Negl. Trop. Dis. 2013. [CrossRef] [PubMed]

172. Idoyaga, J.; Fiorese, C.; Zbytnuik, L.; Lubkin, A.; Miller, J.; Malissen, B.; Mucida, D.; Merad, M.; Steinman, R.M. Specialized role of migratory dendritic cells in peripheral tolerance induction. J. Clin. Investig. 2013, 123, 844-854. [CrossRef] [PubMed]

173. Bates, E.E.; Fournier, N.; Garcia, E.; Valladeau, J.; Durand, I.; Pin, J.J.; Zurawski, S.M.; Patel, S.; Abrams, J.S.; Lebecque, S.; et al. APCs express DCIR, a novel C-type lectin surface receptor containing an immunoreceptor tyrosine-based inhibitory motif. J. Immunol. 1999, 163, 1973-1983. [PubMed]

174. Klechevsky, E.; Flamar, A.L.; Cao, Y.; Blanck, J.P.; Liu, M.; O’Bar, A.; Agouna-Deciat, O.; Klucar, P.; Thompson-Snipes, L.; Zurawski, S.; et al. Cross-priming $\mathrm{CD}^{+} \mathrm{T}$ cells by targeting antigens to human dendritic cells through DCIR. Blood 2010, 116, 1685-1697. [CrossRef] [PubMed]

175. Bloem, K.; Vuist, I.M.; van den Berk, M.; Klaver, E.J.; van Die, I.; Knippels, L.M.; Garssen, J.; Garcia-Vallejo, J.J.; van Vliet, S.J.; van Kooyk, Y. DCIR interacts with ligands from both endogenous and pathogenic origin. Immunol. Lett. 2014, 158, 33-41. [CrossRef] [PubMed]

176. Jin, W.; Li, C.; Du, T.; Hu, K.; Huang, X.; Hu, Q. DC-SIGN plays a stronger role than DCIR in mediating HIV-1 capture and transfer. Virology 2014. [CrossRef] [PubMed]

177. Lambert, A.A.; Gilbert, C.; Richard, M.; Beaulieu, A.D.; Tremblay, M.J. The C-type lectin surface receptor DCIR acts as a new attachment factor for HIV-1 in dendritic cells and contributes to trans- and cis-infection pathways. Blood 2008, 112, 1299-1307. [CrossRef] [PubMed]

178. Idoyaga, J.; Cheong, C.; Suda, K.; Suda, N.; Kim, J.Y.; Lee, H.; Park, C.G.; Steinman, R.M. Cutting edge: Langerin/CD207 receptor on dendritic cells mediates efficient antigen presentation on MHC I and II products in vivo. J. Immunol. 2008, 180, 3647-3650. [CrossRef] [PubMed]

179. Neubert, K.; Lehmann, C.H.; Heger, L.; Baranska, A.; Staedtler, A.M.; Buchholz, V.R.; Yamazaki, S.; Heidkamp, G.F.; Eissing, N.; Zebroski, H.; et al. Antigen delivery to CD11c ${ }^{+}$CD8 ${ }^{-}$dendritic cells induces protective immune responses against experimental melanoma in mice in vivo. J. Immunol. 2014, 192, 5830-5838. [CrossRef] [PubMed]

180. Boscardin, S.B.; Hafalla, J.C.; Masilamani, R.F.; Kamphorst, A.O.; Zebroski, H.A.; Rai, U.; Morrot, A.; Zavala, F.; Steinman, R.M.; Nussenzweig, R.S.; et al. Antigen targeting to dendritic cells elicits long-lived T cell help for antibody responses. J. Exp. Med. 2006, 203, 599-606. [CrossRef] [PubMed]

181. Macho-Fernandez, E.; Cruz, L.J.; Ghinnagow, R.; Fontaine, J.; Bialecki, E.; Frisch, B.; Trottein, F.; Faveeuw, C. Targeted delivery of $\alpha$-galactosylceramide to CD8 $\alpha^{+}$dendritic cells optimizes type I NKT cell-based antitumor responses. J. Immunol. 2014, 193, 961-969. [CrossRef] [PubMed]

182. Do, Y.; Koh, H.; Park, C.G.; Dudziak, D.; Seo, P.; Mehandru, S.; Choi, J.H.; Cheong, C.; Park, S.; Perlin, D.S.; et al . Targeting of LCRV virulence protein from yersinia pestis to dendritic cells protects mice against pneumonic plague. Eur. J. Immunol. 2010, 40, 2791-2796. [CrossRef] [PubMed]

183. Trumpfheller, C.; Finke, J.S.; Lopez, C.B.; Moran, T.M.; Moltedo, B.; Soares, H.; Huang, Y.; Schlesinger, S.J.; Park, C.G.; Nussenzweig, M.C.; et al. Intensified and protective CD4 ${ }^{+} \mathrm{T}$ cell immunity in mice with anti-dendritic cell HIV gag fusion antibody vaccine. J. Exp. Med. 2006, 203, 607-617. [CrossRef] [PubMed]

184. Idoyaga, J.; Lubkin, A.; Fiorese, C.; Lahoud, M.H.; Caminschi, I.; Huang, Y.; Rodriguez, A.; Clausen, B.E.; Park, C.G.; Trumpfheller, C.; et al. Comparable T helper 1 (Th1) and CD8 T-cell immunity by targeting HIV gag p24 to CD8 dendritic cells within antibodies to langerin, DEC205, and Clec9A. Proc. Nat. Acad. Sci. USA 2011, 108, 2384-2389. [CrossRef] [PubMed]

185. Longhi, M.P.; Trumpfheller, C.; Idoyaga, J.; Caskey, M.; Matos, I.; Kluger, C.; Salazar, A.M.; Colonna, M.; Steinman, R.M. Dendritic cells require a systemic type I interferon response to mature and induce CD4 ${ }^{+}$Th1 immunity with poly IC as adjuvant. J. Exp. Med. 2009, 206, 1589-1602. [CrossRef] [PubMed] 
186. Ruane, D.; Chorny, A.; Lee, H.; Faith, J.; Pandey, G.; Shan, M.; Simchoni, N.; Rahman, A.; Garg, A.; Weinstein, E.G.; et al. Microbiota regulate the ability of lung dendritic cells to induce IgA class-switch recombination and generate protective gastrointestinal immune responses. J. Exp. Med. 2016, 213, 53-73. [CrossRef] [PubMed]

187. Spiering, R.; Margry, B.; Keijzer, C.; Petzold, C.; Hoek, A.; Wagenaar-Hilbers, J.; van der Zee, R.; van Eden, W.; Kretschmer, K.; Broere, F. DEC205+ dendritic cell-targeted tolerogenic vaccination promotes immune tolerance in experimental autoimmune arthritis. J. Immunol. 2015, 194, 4804-4813. [CrossRef] [PubMed]

188. Matos, I.; Mizenina, O.; Lubkin, A.; Steinman, R.M.; Idoyaga, J. Targeting antigens to dendritic cells in vivo induces protective immunity. PLoS ONE 2013, 8, e67453.

189. Wang, B.; Zaidi, N.; He, L.Z.; Zhang, L.; Kuroiwa, J.M.; Keler, T.; Steinman, R.M. Targeting of the non-mutated tumor antigen HER2/neu to mature dendritic cells induces an integrated immune response that protects against breast cancer in mice. Breast Cancer Res. 2012. [CrossRef] [PubMed]

190. Rampazo, E.V.; Amorim, K.N.; Yamamoto, M.M.; Panatieri, R.H.; Rodrigues, M.M.; Boscardin, S.B. Antigen targeting to dendritic cells allows the identification of a CD4 T-cell epitope within an immunodominant trypanosoma cruzi antigen. PLoS ONE 2015, 10, e0117778. [CrossRef] [PubMed]

191. Mukhopadhaya, A.; Hanafusa, T.; Jarchum, I.; Chen, Y.G.; Iwai, Y.; Serreze, D.V.; Steinman, R.M.; Tarbell, K.V.; DiLorenzo, T.P. Selective delivery of beta cell antigen to dendritic cells in vivo leads to deletion and tolerance of autoreactive CD8 ${ }^{+}$T cells in nod mice. Proc. Nat. Acad. Sci. USA 2008, 105, 6374-6379. [CrossRef] [PubMed]

192. Petzold, C.; Riewaldt, J.; Koenig, T.; Schallenberg, S.; Kretschmer, K. Dendritic cell-targeted pancreatic beta-cell antigen leads to conversion of self-reactive CD4(+) T cells into regulatory $\mathrm{T}$ cells and promotes immunotolerance in NOD mice. Rev Diabet. Stud. 2010, 7, 47-61. [CrossRef] [PubMed]

193. Charalambous, A.; Oks, M.; Nchinda, G.; Yamazaki, S.; Steinman, R.M. Dendritic cell targeting of survivin protein in a xenogeneic form elicits strong $\mathrm{CD}^{+} \mathrm{T}$ cell immunity to mouse survivin. J. Immunol. 2006, 177, 8410-8421. [CrossRef] [PubMed]

194. Mukherjee, G.; Geliebter, A.; Babad, J.; Santamaria, P.; Serreze, D.V.; Freeman, G.J.; Tarbell, K.V.; Sharpe, A.; DiLorenzo, T.P. DEC-205-mediated antigen targeting to steady-state dendritic cells induces deletion of diabetogenic CD8(+) T cells independently of PD-1 and PD-L1. Int. Immunol. 2013, 25, 651-660. [CrossRef] [PubMed]

195. Stern, J.N.; Keskin, D.B.; Kato, Z.; Waldner, H.; Schallenberg, S.; Anderson, A.; von Boehmer, H.; Kretschmer, K.; Strominger, J.L. Promoting tolerance to proteolipid protein-induced experimental autoimmune encephalomyelitis through targeting dendritic cells. Proc. Nat. Acad. Sci. USA 2010, 107, 17280-17285. [CrossRef] [PubMed]

196. Platt, C.D.; Ma, J.K.; Chalouni, C.; Ebersold, M.; Bou-Reslan, H.; Carano, R.A.; Mellman, I.; Delamarre, L. Mature dendritic cells use endocytic receptors to capture and present antigens. Proc. Nat. Acad. Sci. USA 2010, 107, 4287-4292. [CrossRef] [PubMed]

197. Ring, S.; Maas, M.; Nettelbeck, D.M.; Enk, A.H.; Mahnke, K. Targeting of autoantigens to DEC205(+) dendritic cells in vivo suppresses experimental allergic encephalomyelitis in mice. J. Immunol. 2013, 191, 2938-2947. [CrossRef] [PubMed]

198. Ettinger, M.; Gratz, I.K.; Gruber, C.; Hauser-Kronberger, C.; Johnson, T.S.; Mahnke, K.; Thalhamer, J.; Hintner, H.; Peckl-Schmid, D.; Bauer, J.W. Targeting of the hNC16A collagen domain to dendritic cells induces tolerance to human type XVII collagen. Exp. Dermatol. 2012, 21, 395-398. [PubMed]

199. van Broekhoven, C.L.; Parish, C.R.; Demangel, C.; Britton, W.J.; Altin, J.G. Targeting dendritic cells with antigen-containing liposomes: A highly effective procedure for induction of antitumor immunity and for tumor immunotherapy. Cancer Res. 2004, 64, 4357-4365. [CrossRef] [PubMed]

200. Bonifaz, L.; Bonnyay, D.; Mahnke, K.; Rivera, M.; Nussenzweig, M.C.; Steinman, R.M. Efficient targeting of protein antigen to the dendritic cell receptor DEC-205 in the steady state leads to antigen presentation on major histocompatibility complex class I products and peripheral CD8 ${ }^{+}$T cell tolerance. J. Exp. Med. 2002, 196, 1627-1638. [CrossRef] [PubMed]

201. Flacher, V.; Tripp, C.H.; Haid, B.; Kissenpfennig, A.; Malissen, B.; Stoitzner, P.; Idoyaga, J.; Romani, N. Skin langerin $^{+}$dendritic cells transport intradermally injected anti-DEC-205 antibodies but are not essential for subsequent cytotoxic CD8 ${ }^{+} \mathrm{T}$ cell responses. J. Immunol. 2012, 188, 2146-2155. [CrossRef] [PubMed] 
202. Flacher, V.; Tripp, C.H.; Stoitzner, P.; Haid, B.; Ebner, S.; Del Frari, B.; Koch, F.; Park, C.G.; Steinman, R.M.; Idoyaga, J.; et al. Epidermal Langerhans cells rapidly capture and present antigens from C-type lectin-targeting antibodies deposited in the dermis. J. Investig. Dermatol. 2010, 130, 755-762. [CrossRef] [PubMed]

203. Flynn, B.J.; Kastenmuller, K.; Wille-Reece, U.; Tomaras, G.D.; Alam, M.; Lindsay, R.W.; Salazar, A.M.; Perdiguero, B.; Gomez, C.E.; Wagner, R.; et al. Immunization with HIV gag targeted to dendritic cells followed by recombinant new york vaccinia virus induces robust T-cell immunity in nonhuman primates. Proc. Nat. Acad. Sci. USA 2011, 108, 7131-7136. [CrossRef] [PubMed]

204. Gurer, C.; Strowig, T.; Brilot, F.; Pack, M.; Trumpfheller, C.; Arrey, F.; Park, C.G.; Steinman, R.M.; Munz, C. Targeting the nuclear antigen 1 of Epstein-Barr virus to the human endocytic receptor DEC-205 stimulates protective T-cell responses. Blood 2008, 112, 1231-1239. [CrossRef] [PubMed]

205. Bozzacco, L.; Trumpfheller, C.; Siegal, F.P.; Mehandru, S.; Markowitz, M.; Carrington, M.; Nussenzweig, M.C.; Piperno, A.G.; Steinman, R.M. DEC-205 receptor on dendritic cells mediates presentation of HIV gag protein to $\mathrm{CD}^{+} \mathrm{T}$ cells in a spectrum of human MHC I haplotypes. Proc. Nat. Acad. Sci. USA 2007, 104, 1289-1294. [CrossRef] [PubMed]

206. Tsuji, T.; Matsuzaki, J.; Kelly, M.P.; Ramakrishna, V.; Vitale, L.; He, L.Z.; Keler, T.; Odunsi, K.; Old, L.J.; Ritter, G.; et al. Antibody-targeted NY-ESO-1 to mannose receptor or DEC-205 in vitro elicits dual human $\mathrm{CD}^{+}$and $\mathrm{CD}^{+} \mathrm{T}$ cell responses with broad antigen specificity. J. Immunol. 2011, 186, 1218-1227. [CrossRef] [PubMed]

207. Birkholz, K.; Schwenkert, M.; Kellner, C.; Gross, S.; Fey, G.; Schuler-Thurner, B.; Schuler, G.; Schaft, N.; Dorrie, J. Targeting of DEC-205 on human dendritic cells results in efficient mhc class II-restricted antigen presentation. Blood 2010, 116, 2277-2285. [CrossRef] [PubMed]

208. White, A.L.; Tutt, A.L.; James, S.; Wilkinson, K.A.; Castro, F.V.; Dixon, S.V.; Hitchcock, J.; Khan, M.; Al-Shamkhani, A.; Cunningham, A.F.; et al. Ligation of CD11c during vaccination promotes germinal centre induction and robust humoral responses without adjuvant. Immunology 2010, 131, 141-151. [CrossRef] [PubMed]

209. Sancho, D.; Mourao-Sa, D.; Joffre, O.P.; Schulz, O.; Rogers, N.C.; Pennington, D.J.; Carlyle, J.R.; Reis e Sousa, C. Tumor therapy in mice via antigen targeting to a novel, DC-restricted C-type lectin. J. Clin. Investig. 2008, 118, 2098-2110. [CrossRef] [PubMed]

210. Joffre, O.P.; Sancho, D.; Zelenay, S.; Keller, A.M.; Reis e Sousa, C. Efficient and versatile manipulation of the peripheral CD4 ${ }^{+}$T-cell compartment by antigen targeting to DNGR-1/CLEC9A. Eur. J. Immunol. 2010, 40, 1255-1265. [CrossRef] [PubMed]

211. Caminschi, I.; Proietto, A.I.; Ahmet, F.; Kitsoulis, S.; Shin Teh, J.; Lo, J.C.; Rizzitelli, A.; Wu, L.; Vremec, D.; van Dommelen, S.L.; et al. The dendritic cell subtype-restricted C-type lectin Clec9A is a target for vaccine enhancement. Blood 2008, 112, 3264-3273. [CrossRef] [PubMed]

212. Lahoud, M.H.; Ahmet, F.; Kitsoulis, S.; Wan, S.S.; Vremec, D.; Lee, C.N.; Phipson, B.; Shi, W.; Smyth, G.K.; Lew, A.M.; et al. Targeting antigen to mouse dendritic cells via Clec9A induces potent CD4 T cell responses biased toward a follicular helper phenotype. J. Immunol. 2011, 187, 842-850. [CrossRef] [PubMed]

213. Schreibelt, G.; Klinkenberg, L.J.; Cruz, L.J.; Tacken, P.J.; Tel, J.; Kreutz, M.; Adema, G.J.; Brown, G.D.; Figdor, C.G.; de Vries, I.J. The C-type lectin receptor Clec9A mediates antigen uptake and (cross ${ }^{-}$) presentation by human blood $\mathrm{BDCA3}^{+}$myeloid dendritic cells. Blood 2012, 119, 2284-2292. [CrossRef] [PubMed]

214. Lahoud, M.H.; Proietto, A.I.; Ahmet, F.; Kitsoulis, S.; Eidsmo, L.; Wu, L.; Sathe, P.; Pietersz, S.; Chang, H.W.; Walker, I.D.; et al. The C-type lectin clec12a present on mouse and human dendritic cells can serve as a target for antigen delivery and enhancement of antibody responses. J. Immunol. 2009, 182, 7587-7594. [CrossRef] [PubMed]

215. Carter, R.W.; Thompson, C.; Reid, D.M.; Wong, S.Y.; Tough, D.F. Preferential induction of CD4 ${ }^{+}$T cell responses through in vivo targeting of antigen to dendritic cell-associated C-type lectin-1. J. Immunol. 2006, 177, 2276-2284. [CrossRef] [PubMed]

216. Duluc, D.; Joo, H.; Ni, L.; Yin, W.; Upchurch, K.; Li, D.; Xue, Y.; Klucar, P.; Zurawski, S.; Zurawski, G.; et al. Induction and activation of human Th17 by targeting antigens to dendritic cells via Dectin-1. J. Immunol. 2014, 192, 5776-5788. [CrossRef] [PubMed]

217. Ni, L.; Gayet, I.; Zurawski, S.; Duluc, D.; Flamar, A.L.; Li, X.H.; O’Bar, A.; Clayton, S.; Palucka, A.K.; Zurawski, G.; et al. Concomitant activation and antigen uptake via human Dectin-1 results in potent antigen-specific CD8 ${ }^{+} \mathrm{T}$ cell responses. J. Immunol. 2010, 185, 3504-3513. [CrossRef] [PubMed] 
218. Flacher, V.; Tripp, C.H.; Mairhofer, D.G.; Steinman, R.M.; Stoitzner, P.; Idoyaga, J.; Romani, N. Murine langerin $^{+}$dermal dendritic cells prime $\mathrm{CD}^{+} \mathrm{T}$ cells while langerhans cells induce cross-tolerance. EMBO Mol. Med. 2014, 6, 1191-1204. [CrossRef] [PubMed]

219. Tacken, P.J.; de Vries, I.J.; Gijzen, K.; Joosten, B.; Wu, D.; Rother, R.P.; Faas, S.J.; Punt, C.J.; Torensma, R.; Adema, G.J.; et al. Effective induction of naive and recall T-cell responses by targeting antigen to human dendritic cells via a humanized anti-DC-SIGN antibody. Blood 2005, 106, 1278-1285. [CrossRef] [PubMed]

220. Hesse, C.; Ginter, W.; Forg, T.; Mayer, C.T.; Baru, A.M.; Arnold-Schrauf, C.; Unger, W.W.; Kalay, H.; van Kooyk, Y.; Berod, L.; et al. In vivo targeting of human DC-SIGN drastically enhances CD8(+) T-cell-mediated protective immunity. Eur. J. Immunol. 2013, 43, 2543-2553. [CrossRef] [PubMed]

221. Tacken, P.J.; Ginter, W.; Berod, L.; Cruz, L.J.; Joosten, B.; Sparwasser, T.; Figdor, C.G.; Cambi, A. Targeting DC-SIGN via its neck region leads to prolonged antigen residence in early endosomes, delayed lysosomal degradation, and cross-presentation. Blood 2011, 118, 4111-4119. [CrossRef] [PubMed]

222. Pereira, C.F.; Torensma, R.; Hebeda, K.; Kretz-Rommel, A.; Faas, S.J.; Figdor, C.G.; Adema, G.J. In vivo targeting of DC-SIGN-positive antigen-presenting cells in a nonhuman primate model. J. Immunother. 2007, 30, 705-714. [CrossRef] [PubMed]

223. Kretz-Rommel, A.; Qin, F.; Dakappagari, N.; Torensma, R.; Faas, S.; Wu, D.; Bowdish, K.S. In vivo targeting of antigens to human dendritic cells through DC-SIGN elicits stimulatory immune responses and inhibits tumor growth in grafted mouse models. J. Immunother. 2007, 30, 715-726. [CrossRef] [PubMed]

224. He, L.Z.; Ramakrishna, V.; Connolly, J.E.; Wang, X.T.; Smith, P.A.; Jones, C.L.; Valkova-Valchanova, M.; Arunakumari, A.; Treml, J.F.; Goldstein, J.; et al. A novel human cancer vaccine elicits cellular responses to the tumor-associated antigen, human chorionic gonadotropin beta. Clin. Cancer Res. 2004, 10, 1920-1927. [CrossRef] [PubMed]

225. Ramakrishna, V.; Treml, J.F.; Vitale, L.; Connolly, J.E.; O’Neill, T.; Smith, P.A.; Jones, C.L.; He, L.Z.; Goldstein, J.; Wallace, P.K.; et al. Mannose receptor targeting of tumor antigen pmel17 to human dendritic cells directs anti-melanoma T cell responses via multiple HLA molecules. J. Immunol. 2004, 172, 2845-2852. [CrossRef] [PubMed]

226. Ramakrishna, V.; Vasilakos, J.P.; Tario, J.D., Jr.; Berger, M.A.; Wallace, P.K.; Keler, T. Toll-like receptor activation enhances cell-mediated immunity induced by an antibody vaccine targeting human dendritic cells. J. Transl. Med. 2007. [CrossRef] [PubMed]

227. Castro, F.V.; Tutt, A.L.; White, A.L.; Teeling, J.L.; James, S.; French, R.R.; Glennie, M.J. CD11c provides an effective immunotarget for the generation of both CD4 and CD8 T cell responses. Eur. J. Immunol. 2008, 38, 2263-2273. [CrossRef] [PubMed]

228. Wei, H.; Wang, S.; Zhang, D.; Hou, S.; Qian, W.; Li, B.; Guo, H.; Kou, G.; He, J.; Wang, H.; et al. Targeted delivery of tumor antigens to activated dendritic cells via CD11c molecules induces potent antitumor immunity in mice. Clin. Cancer Res. 2009, 15, 4612-4621. [CrossRef] [PubMed]

229. Dickgreber, N.; Stoitzner, P.; Bai, Y.; Price, K.M.; Farrand, K.J.; Manning, K.; Angel, C.E.; Dunbar, P.R.; Ronchese, F.; Fraser, J.D.; et al. Targeting antigen to MHC class II molecules promotes efficient cross-presentation and enhances immunotherapy. J. Immunol. 2009, 182, 1260-1269. [CrossRef] [PubMed]

230. Delneste, Y.; Magistrelli, G.; Gauchat, J.; Haeuw, J.; Aubry, J.; Nakamura, K.; Kawakami-Honda, N.; Goetsch, L.; Sawamura, T.; Bonnefoy, J.; et al. Involvement of LOX-1 in dendritic cell-mediated antigen cross-presentation. Immunity 2002, 17, 353-362. [CrossRef]

231. Joo, H.; Li, D.; Dullaers, M.; Kim, T.W.; Duluc, D.; Upchurch, K.; Xue, Y.; Zurawski, S.; Le Grand, R.; Liu, Y.J.; et al. C-type lectin-like receptor LOX-1 promotes dendritic cell-mediated class-switched B cell responses. Immunity 2014, 41, 592-604. [CrossRef] [PubMed]

232. Li, D.; Romain, G.; Flamar, A.L.; Duluc, D.; Dullaers, M.; Li, X.H.; Zurawski, S.; Bosquet, N.; Palucka, A.K.; Le Grand, R.; et al. Targeting self- and foreign antigens to dendritic cells via DC-asgpr generates IL-10-producing suppressive CD4 ${ }^{+}$T cells. J. Exp. Med. 2012, 209, 109-121. [CrossRef] [PubMed]

233. Tagliani, E.; Guermonprez, P.; Sepulveda, J.; Lopez-Bravo, M.; Ardavin, C.; Amigorena, S.; Benvenuti, F.; Burrone, O.R. Selection of an antibody library identifies a pathway to induce immunity by targeting CD36 on steady-state CD8 $\alpha^{+}$dendritic cells. J. Immunol. 2008, 180, 3201-3209. [CrossRef] [PubMed]

234. Zhang, J.; Raper, A.; Sugita, N.; Hingorani, R.; Salio, M.; Palmowski, M.J.; Cerundolo, V.; Crocker, P.R. Characterization of Siglec-H as a novel endocytic receptor expressed on murine plasmacytoid dendritic cell precursors. Blood 2006, 107, 3600-3608. [CrossRef] [PubMed] 
235. Sapoznikov, A.; Fischer, J.A.; Zaft, T.; Krauthgamer, R.; Dzionek, A.; Jung, S. Organ-dependent in vivo priming of naive $\mathrm{CD}^{+}$, but not $\mathrm{CD}^{+}$, T cells by plasmacytoid dendritic cells. J. Exp. Med. 2007, 204, 1923-1933. [CrossRef] [PubMed]

236. Price, J.D.; Tarbell, K.V. The role of dendritic cell subsets and innate immunity in the pathogenesis of type 1 diabetes and other autoimmune diseases. Front. Immunol. 2015. [CrossRef] [PubMed]

237. Ruane, D.; Do, Y.; Brane, L.; Garg, A.; Bozzacco, L.; Kraus, T.; Caskey, M.; Salazar, A.; Trumpheller, C.; Mehandru, S. A dendritic cell targeted vaccine induces long-term HIV-specific immunity within the gastrointestinal tract. Mucosal Immunol. 2016. [CrossRef] [PubMed]

238. Engering, A.; Geijtenbeek, T.B.; van Vliet, S.J.; Wijers, M.; van Liempt, E.; Demaurex, N.; Lanzavecchia, A.; Fransen, J.; Figdor, C.G.; Piguet, V.; et al. The dendritic cell-specific adhesion receptor DC-SIGN internalizes antigen for presentation to T cells. J. Immunol. 2002, 168, 2118-2126. [CrossRef] [PubMed]

239. Lai, W.K.; Sun, P.J.; Zhang, J.; Jennings, A.; Lalor, P.F.; Hubscher, S.; McKeating, J.A.; Adams, D.H. Expression of DC-SIGN and DC-SIGNR on human sinusoidal endothelium: A role for capturing hepatitis C virus particles. Am. J. Pathol. 2006, 169, 200-208. [CrossRef] [PubMed]

240. Segura, E.; Valladeau-Guilemond, J.; Donnadieu, M.H.; Sastre-Garau, X.; Soumelis, V.; Amigorena, S. Characterization of resident and migratory dendritic cells in human lymph nodes. J. Exp. Med. 2012, 209, 653-660. [CrossRef] [PubMed]

241. Garcia-Vallejo, J.J.; van Kooyk, Y. The physiological role of DC-SIGN: A tale of mice and men. Trends Immunol. 2013, 34, 482-486. [CrossRef] [PubMed]

242. Park, C.G.; Takahara, K.; Umemoto, E.; Yashima, Y.; Matsubara, K.; Matsuda, Y.; Clausen, B.E.; Inaba, K.; Steinman, R.M. Five mouse homologues of the human dendritic cell C-type lectin, DC-SIGN. Int. Immunol. 2001, 13, 1283-1290. [CrossRef] [PubMed]

243. Powlesland, A.S.; Ward, E.M.; Sadhu, S.K.; Guo, Y.; Taylor, M.E.; Drickamer, K. Widely divergent biochemical properties of the complete set of mouse DC-SIGN-related proteins. J. Biol. Chem. 2006, 281, 20440-20449. [CrossRef] [PubMed]

244. Schaefer, M.; Reiling, N.; Fessler, C.; Stephani, J.; Taniuchi, I.; Hatam, F.; Yildirim, A.O.; Fehrenbach, H.; Walter, K.; Ruland, J.; et al. Decreased pathology and prolonged survival of human DC-SIGN transgenic mice during mycobacterial infection. J. Immunol. 2008, 180, 6836-6845. [CrossRef] [PubMed]

245. Caparros, E.; Munoz, P.; Sierra-Filardi, E.; Serrano-Gomez, D.; Puig-Kroger, A.; Rodriguez-Fernandez, J.L.; Mellado, M.; Sancho, J.; Zubiaur, M.; Corbi, A.L. DC-SIGN ligation on dendritic cells results in ERK and PI3K activation and modulates cytokine production. Blood 2006, 107, 3950-3958. [CrossRef] [PubMed]

246. Bachem, A.; Guttler, S.; Hartung, E.; Ebstein, F.; Schaefer, M.; Tannert, A.; Salama, A.; Movassaghi, K.; Opitz, C.; Mages, H.W.; et al. Superior antigen cross-presentation and XCR1 expression define human

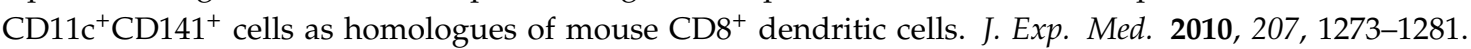
[CrossRef] [PubMed]

247. Crozat, K.; Guiton, R.; Guilliams, M.; Henri, S.; Baranek, T.; Schwartz-Cornil, I.; Malissen, B.; Dalod, M. Comparative genomics as a tool to reveal functional equivalences between human and mouse dendritic cell subsets. Immunol. Rev. 2010, 234, 177-198. [CrossRef] [PubMed]

248. Jongbloed, S.L.; Kassianos, A.J.; McDonald, K.J.; Clark, G.J.; Ju, X.; Angel, C.E.; Chen, C.J.; Dunbar, P.R.; Wadley, R.B.; Jeet, V.; et al. Human CD141 ${ }^{+}$(BDCA-3) ${ }^{+}$dendritic cells (DCs) represent a unique myeloid DC subset that cross-presents necrotic cell antigens. J. Exp. Med. 2010, 207, 1247-1260. [CrossRef] [PubMed]

249. Lundberg, K.; Rydnert, F.; Greiff, L.; Lindstedt, M. Human blood dendritic cell subsets exhibit discriminative pattern recognition receptor profiles. Immunology 2014, 142, 279-288. [CrossRef] [PubMed]

250. Poulin, L.F.; Salio, M.; Griessinger, E.; Anjos-Afonso, F.; Craciun, L.; Chen, J.L.; Keller, A.M.; Joffre, O.; Zelenay, S.; Nye, E.; et al. Characterization of human DNGR-1 ${ }^{+} \mathrm{BDCA3}^{+}$leukocytes as putative equivalents of mouse CD8 $\alpha^{+}$dendritic cells. J. Exp. Med. 2010, 207, 1261-1271. [CrossRef] [PubMed]

251. Watchmaker, P.B.; Lahl, K.; Lee, M.; Baumjohann, D.; Morton, J.; Kim, S.J.; Zeng, R.; Dent, A.; Ansel, K.M.; Diamond, B.; et al. Comparative transcriptional and functional profiling defines conserved programs of intestinal DC differentiation in humans and mice. Nat. Immunol. 2014, 15, 98-108. [CrossRef] [PubMed]

252. Chatterjee, B.; Smed-Sorensen, A.; Cohn, L.; Chalouni, C.; Vandlen, R.; Lee, B.C.; Widger, J.; Keler, T.; Delamarre, L.; Mellman, I. Internalization and endosomal degradation of receptor-bound antigens regulate the efficiency of cross presentation by human dendritic cells. Blood 2012, 120, 2011-2020. [CrossRef] [PubMed] 
253. Keler, T.; Ramakrishna, V.; Fanger, M.W. Mannose receptor-targeted vaccines. Expert Opin. Biol. Ther. 2004, 4 , 1953-1962. [CrossRef] [PubMed]

254. Drummond, R.A.; Brown, G.D. Signalling C-type lectins in antimicrobial immunity. PLoS Pathog. $2013,9$. [CrossRef] [PubMed]

255. Killick, K.E.; Ni Cheallaigh, C.; O’Farrelly, C.; Hokamp, K.; MacHugh, D.E.; Harris, J. Receptor-mediated recognition of mycobacterial pathogens. Cell. Microbiol. 2013, 15, 1484-1495. [CrossRef] [PubMed]

256. Willment, J.A.; Marshall, A.S.; Reid, D.M.; Williams, D.L.; Wong, S.Y.; Gordon, S.; Brown, G.D. The human beta-glucan receptor is widely expressed and functionally equivalent to murine Dectin-1 on primary cells. Eur. J. Immunol. 2005, 35, 1539-1547. [CrossRef] [PubMed]

257. Ruland, J. CARD9 signaling in the innate immune response. Ann. N. Y. Acad. Sci. 2008, 1143, 35-44. [CrossRef] [PubMed]

258. Robinson, M.J.; Sancho, D.; Slack, E.C.; LeibundGut-Landmann, S.; Reis e Sousa, C. Myeloid C-type lectins in innate immunity. Nat. Immunol. 2006, 7, 1258-1265. [CrossRef] [PubMed]

259. Reid, D.M.; Montoya, M.; Taylor, P.R.; Borrow, P.; Gordon, S.; Brown, G.D.; Wong, S.Y. Expression of the beta-glucan receptor, Dectin-1, on murine leukocytes in situ correlates with its function in pathogen recognition and reveals potential roles in leukocyte interactions. J. Leukoc. Biol. 2004, 76, 86-94. [CrossRef] [PubMed]

260. Romani, N.; Clausen, B.E.; Stoitzner, P. Langerhans cells and more: Langerin-expressing dendritic cell subsets in the skin. Immunol. Rev. 2010, 234, 120-141. [CrossRef] [PubMed]

261. Valladeau, J.; Ravel, O.; Dezutter-Dambuyant, C.; Moore, K.; Kleijmeer, M.; Liu, Y.; Duvert-Frances, V.; Vincent, C.; Schmitt, D.; Davoust, J.; et al. Langerin, a novel C-type lectin specific to langerhans cells, is an endocytic receptor that induces the formation of birbeck granules. Immunity 2000, 12, 71-81. [CrossRef]

262. Valladeau, J.; Duvert-Frances, V.; Pin, J.J.; Kleijmeer, M.J.; Ait-Yahia, S.; Ravel, O.; Vincent, C.; Vega, F., Jr.; Helms, A.; Gorman, D.; et al. Immature human dendritic cells express asialoglycoprotein receptor isoforms for efficient receptor-mediated endocytosis. J. Immunol. 2001, 167, 5767-5774. [CrossRef] [PubMed]

263. Wang, H.; Griffiths, M.N.; Burton, D.R.; Ghazal, P. Rapid antibody responses by low-dose, single-step, dendritic cell-targeted immunization. Proc. Nat. Acad. Sci. USA 2000, 97, 847-852. [CrossRef] [PubMed]

264. Krug, A.; French, A.R.; Barchet, W.; Fischer, J.A.; Dzionek, A.; Pingel, J.T.; Orihuela, M.M.; Akira, S.; Yokoyama, W.M.; Colonna, M. TLR9-dependent recognition of MCMV by IPC and DC generates coordinated cytokine responses that activate antiviral NK cell function. Immunity 2004, 21, 107-119. [CrossRef] [PubMed]

265. Blasius, A.L.; Giurisato, E.; Cella, M.; Schreiber, R.D.; Shaw, A.S.; Colonna, M. Bone marrow stromal cell antigen 2 is a specific marker of type I IFN-producing cells in the naive mouse, but a promiscuous cell surface antigen following IFN stimulation. J. Immunol. 2006, 177, 3260-3265. [CrossRef] [PubMed]

266. Pugholm, L.H.; Petersen, L.R.; Sondergaard, E.K.; Varming, K.; Agger, R. Enhanced humoral responses induced by targeting of antigen to murine dendritic cells. Scand. J. Immunol. 2015, 82, 515-522. [CrossRef] [PubMed]

267. Maisonnasse, P.; Bouguyon, E.; Piton, G.; Ezquerra, A.; Urien, C.; Deloizy, C.; Bourge, M.; Leplat, J.J.; Simon, G.; Chevalier, C.; et al. The respiratory DC/macrophage network at steady-state and upon influenza infection in the swine biomedical model. Mucosal Immunol. 2015. [CrossRef] [PubMed]

(C) 2016 by the authors; licensee MDPI, Basel, Switzerland. This article is an open access article distributed under the terms and conditions of the Creative Commons by Attribution (CC-BY) license (http://creativecommons.org/licenses/by/4.0/). 